DISCHARGE RATINGS FOR CONTROL GATES

AT MISSISSIPPI RIVER LOCK AND DAM 17,

NEW BOSTON, ILLINOIS

By Albert J. Heinitz

U.S. GEOLOGICAL SURVEY

Water Resources Investigations Report 87-4165

Prepared in cooperation with the

U.S. ARMY CORPS OF ENG INEERS,

ROCK ISLAND DISTRICT

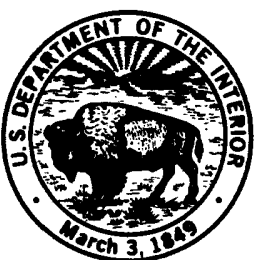

Iowa City, Iowa 


\author{
DEPARTMENT OF THE INTERIOR \\ DONALD PAUL HODEL, Secretary \\ U.S. GEOLOGICAL SURVEY \\ Dallas L. Peck, Director
}

For additional information, write to:

District Chief

Water Resources Division

P.O. Box 1230

Iowa City, Iowa 52244
Copies of this report can be purchased from:

U.S. Geological Survey Books and Open-File Reports Section, Federal Center Box 25425 Denver, Colorado 80225 
CONTENTS

Page

Abstract--

Introduction-

Purpose and Scope--

Acknowledgements--

Location of study area- 4

Flow-control structures- 4

Dam Operation- 7

Discharge and stage measurements- 11

Tainter-gate flow-

Computation of gate opening

Submerged-orifice flow coefficients-

Submerged-orifice discharge equation--

Free-weir flow coefficients- 22

Free-weir discharge equation- 24

Roller gate flow-

Gate opening

Submerged-orifice flow coefficient--

Submerged-orifice discharge equation-

Free-weir flow coefficient-

Free-weir discharge equation-

Discharge equations and ratings- 34

Summary-

Selected references- 


\section{ILLUSTRATIONS}

Page

Figure 1. Map of Inland Waterway Navigation System of the upper Mississippi River basin-- 5

2. Map showing location of flow-control structures--- 8

3. Diagram showing sectional views of tainter and roller gates-- 9

4. Diagram showing details of tainter gates at Mississippi River Lock and Dam 17- 15

5. Graph showing gage-indicator corrections and comparison of gate openings and discharges at 3.0foot gage-indicator settings for tainter gates on Mississippi River Lock and Dam 17-_- 17

6. Graph showing relation between submerged-orifice flow coefficient and orifice-submergence ratio for Lock and Dam 17 tainter gates-_- 19

7. Graph showing comparison of current-meter discharge measurements of February 2, 1987, to rating curve for tainter gates- 21

8. Graph showing relation between free-weir flow coefficient and static-headwater head for tainter gates in submerged position for Lock and Dam 17--- 23

9. Graph showing relation between discharge and headwater for free-wier flow for tainter gates in submerged position for Lock and Dam 17--.-.- 25

10. Graph showing relation between submerged-orifice flow coefficient and orifice-submergence ratio for roller gates at Lock and Dam 17- 27

11. Diagrams showing positions of roller gates for selected crests and openings- 28

12. Graph showing relation between free-weir flow coefficient and static-headwater head for roller gates in submerged position for Lock and Dam 17--- 32 


\section{ILLUSTRATIONS--continued}

13. Graph showing relation between discharge and

Page headwater for free-weir flow for roller gates in submerged position for Lock and Dam 17-- 33

14. Graph showing discharge ratings for submergedorifice flow for a single tainter gate at Mississippi River Lock and Dam 17 compared to hydraulic-model ratings--_- 38

15. Graph showing discharge ratings for submergedorifice flow for a single roller gate at Mississippi River Lock and Dam 17 compared to hydraulic-model ratings-_-_- 39

TABLES

Table 1. Flow-control structures and their respective flow regimes and hydraulic equations-1- 6

2. Summary of current-meter discharge measurements and hydraulic-control data for control gates at Mississippi River Lock and Dam 17- 12

3. Summary of discharge equations for control gates at Mississippi river Lock and Dam 17-_- 35

4. Discharge rating table for submerged-orifice flow for a single tainter gate at Mississippi River Lock and Dam 17 with upstream stage of 9.30 feet--.---- 36

5. Discharge rating table for submerged-orifice flow for a single roller gate at Mississippi River Lock and Dam 17 with upstream pool stage of 9.30 feet---- 37

6. Comparison of rating discharges to discharges specified in Gate Operation Schedule Plan A for Mississippi River Lock and Dam 17-_._._. 40 


\section{SYMBOLS AND UNITS}

A

a

B

C

gs

$C_{\text {sw }}$

$c_{\text {sws }}$

$\mathrm{C}_{\boldsymbol{W}}$

$\mathrm{C}_{\text {wS }}$

g

G

$\mathrm{H}_{1}$

$\mathrm{h}_{1}$

$\mathrm{h}_{3}$

$\mathrm{H}_{1 \mathrm{~s}}$

$\mathrm{h}_{1 \mathrm{~s}}$

$h_{3 s}$
Length times width of lock chamber

Elevation difference, trunnion centerline to sill

Lateral width of a gate opening or fixed spillway

Free-orifice flow coefficient of discharge

Submerged-orifice flow coefficient of discharge

Free-weir flow coefficient of discharge, gate crest or

fixed spillway

Submerged-weir flow coefficient of discharge, gate crest or fixed spillway

Free-weir flow coefficient of discharge, gate sill

Submerged-weir flow coefficient of discharge, gate sill

Acceleration due to gravity

$\mathrm{ft} / \mathrm{s}^{2}$

Gate-position indicator reading

ft

Total headwater head including velocity head referenced to gate sill

ft

Static-headwater head referenced to gate sill

Static-tailwater head referenced to gate sill

$f t$

$f t$

Total headwater head including velocity head referenced

to the gate crest or fixed spillway crest

ft

Static-headwater head referenced to gate crest or

fixed spillway crest

ft

Static-tailwater head referenced to gate crest or

fixed spillway crest $f t^{2}$

$\mathrm{ft}$

ft 
SYMBOLS AND UNITS--continued

Symbol

Definition

Unit

\begin{tabular}{|c|c|c|}
\hline$h_{g}$ & Gate opening & ft \\
\hline $\mathbf{N}$ & Number of lockages occurring between recordings & \\
\hline Q & Computed discharge & $\mathrm{ft}^{3} / \mathrm{s}$ \\
\hline$Q_{I}$ & Computed lock-chamber discharge & $\mathrm{ft}^{3} / \mathrm{s}$ \\
\hline $\mathbf{R}$ & $\begin{array}{l}\text { Radius from trunnion centerline to upstream face of a } \\
\text { tainter gate }\end{array}$ & ft \\
\hline R.P. & $\begin{array}{l}\text { Reference point to which elevations are run for the } \\
\text { purpose of computing the gate opening }\end{array}$ & \\
\hline $\mathbf{r}$ & Radius from trunnion centerline to gate R.P. & ft \\
\hline$\Delta \mathrm{h}^{\prime} \mathrm{h}_{1}-\mathrm{h}_{3}$ & Static-head loss through structure & $\mathrm{ft}$ \\
\hline$\Delta t$ & Time between recordings & sec \\
\hline$\theta$ & $\begin{array}{l}\text { Included angle between radial lines from the trunnion } \\
\text { centerline through the R.P. and through the lower lip } \\
\text { of the gate }\end{array}$ & $\operatorname{deg}$ \\
\hline$\phi$ & $\begin{array}{l}\text { The angle measured from the horizontal to the radial } \\
\text { line from the trunnion centerline through the gate }\end{array}$ & \\
\hline & R.P. with the gate in a closed position & deg \\
\hline$<$ & Less than & \\
\hline$>$ & Greater than & \\
\hline & Equal to or greater than & \\
\hline
\end{tabular}


FACTORS FOR CONVERTING INCH-POUND UNITS TO INTERNATIONAL SYSTEM UNITS (SI)

The following factors may be used to convert the inch-pound units published herein to metric (International system) units:

Multiply inch-pound unit

foot $(f t)$

mile

square foot $\left(f t^{2}\right)$

cubic foot per second $(\mathrm{ft} / \mathrm{s})$

foot $\mathrm{per}_{(\mathrm{ft} / \mathrm{s}}$ ) second squared
\[ \]

pound
By

-Length-

0.3048

1.609

-Area-

0.0929

-Flow-

0.02832

-Acceleration-

0.3048

-Weight-

0.4536
To obtain metric unit

meter

kilometer

square meter

cubic meter per second

meter per second squared

kilogram

Note: The numerical values of the flow coefficients of discharge given in this report can only be used in the English (inch-pound) units. 


\title{
DISCHARGE RATINGS FOR CONTROL GATES \\ AT MISSISSIPPI RIVER LOCK AND DAM 17, NEW BOSTON, ILLINOIS
}

\author{
By Albert J. Heinitz
}

\begin{abstract}
The water levels of the navigation pools on the Mississippi River are maintained by the operation of tainter and roller gates at the locks and dams. Discharge ratings for the gates on Lock and Dam 17, at New Boston, Illinois, were developed from current-meter discharge measurements made in the forebays of the gate structures. Methodology is given to accurately compute the gate openings of the tainter gates. Discharge coefficients, in equations that express discharge as a function of tailwater head, forebay head, and height of gate opening, were determined for conditions of submerged-orifice and freeweir flow. A comparison of the rating discharges to the hydraulic-model rating discharges is given for submerged orifice flow for the tainter and roller gates.
\end{abstract}




\section{INTRODUCTION}

The present navigation system on the upper Mississipppi River between St. Paul, Minnesota, and St. Louis, Missouri, was initiated in 1930 when Congress passed the River and Harbor Act authorizing funds for its development. This legislation provided for a navigation channel at least 9 feet deep and 400 feet wide, to be established by constructing a series of locks and dams, and maintained by channel dredging. The dams create a series of "steps" which allow towboats or other river vessels to travel upstream or downstream. Each dam controls the level of its pool and the locks lift or lower vessels from one pool to the next. Lock and Dam 17 was placed in operation May 14, 1939.

This is the ninth in a series of reports that relate to discharge ratings and hydraulic characteristics of the control gates at locks and dams on the Mississippi River. The other eight reports present similar information for Locks and Dams 11, 12, 13, 14, 16, 18, 20 and 22 (Heinitz, 1985, 1986, 1987). Discharge ratings for these Locks and Dams corroborated rating development for Lock and Dam 17. 


\section{Purpose and Scope}

Central to the efficient operation of the navigation system is the availability of reliable discharge ratings for the flow-control structures. The purpose of this report is to describe the results of a study to develop discharge ratings for the control gates at Lock and Dam 17 . The ratings were developed by using the results of current-meter discharge measurements, made in the forebays of the control-gate structures, to verify and evaluate the discharge coefficients for the theoretical discharge equations. Discharge ratings (U.S. Army Corps of Engineers, 1940) originally developed from laboratory tests on hydraulic models of the gates had never been verified with field data.

The scope of the work covered in this report includes results of currentmeter discharge measurements, methodology for computing tainter-gate openings, development of discharge coefficients and equations of discharge, definition of rating tables of discharge for submerged-orifice flow, comparison of submerged-orifice flow discharges to hydraulic-model rating discharges, and a comparison of discharges computed from methods described in this study to those listed in the U.S. Army Corps of Engineers' gate operation schedule for Lock and Dam 17.

\section{Acknowledgments}

This project was completed in cooperation with the U.S. Army Corps of Engineers, Rock Island District. Special acknowledgement is given to the Corps' Lockmaster for arranging to have the gates adjusted as needed for the measurements. 


\section{LOCATION OF STUDY AREA}

Lock and Dam 17, located at New Boston, Illinois, is a unit of the Inland Waterway Navigation System of the upper Mississippi River Basin. The part of the navigation system within the Rock Island District (U.S. Army Corps of Engineers, 1980, pl. 1) is shown in figure 1.

\section{FLOW-CONTROL STRUCTURES}

Four types of flow-control structures are present at Lock and Dam 17. These are tainter gates, roller gates, navigation lock and a fixed spillway. Detailed theoretical as well as physical descriptions of these flow-control structures are beyond the scope of this report, and, therefore, are not included. Readers interested in this subject are referred to Davis and Sorensen (1952), Rouse (1949), Creager and Justin (1950) and King and Brater (1954). The hydraulic conditions that define each flow regime and the corresponding generalized steady-state discharge equations for the flowcontrol structures are summarized in table 1. An important parameter common to all types of flow-control structures is the discharge coefficient.

The discharge coefficients are functions of various independent hydrauliccontrol variables, of which the most significant are: the static-headwater head $\left(h_{1}\right)$, the static-tailwater head $\left(h_{3}\right)$, and the gate opening $\left(h_{g}\right)$. A discharge coefficient is defined as the ratio of measured discharge to theoretical discharge (ASCE, 1962). Discharge coefficients are determined by measuring discharge during conditions when the hydraulic-control variables are known and fixed. This procedure, referred to as calibration, may be performed on a hydraulic model under controlled laboratory conditions or in the field at the dam. 


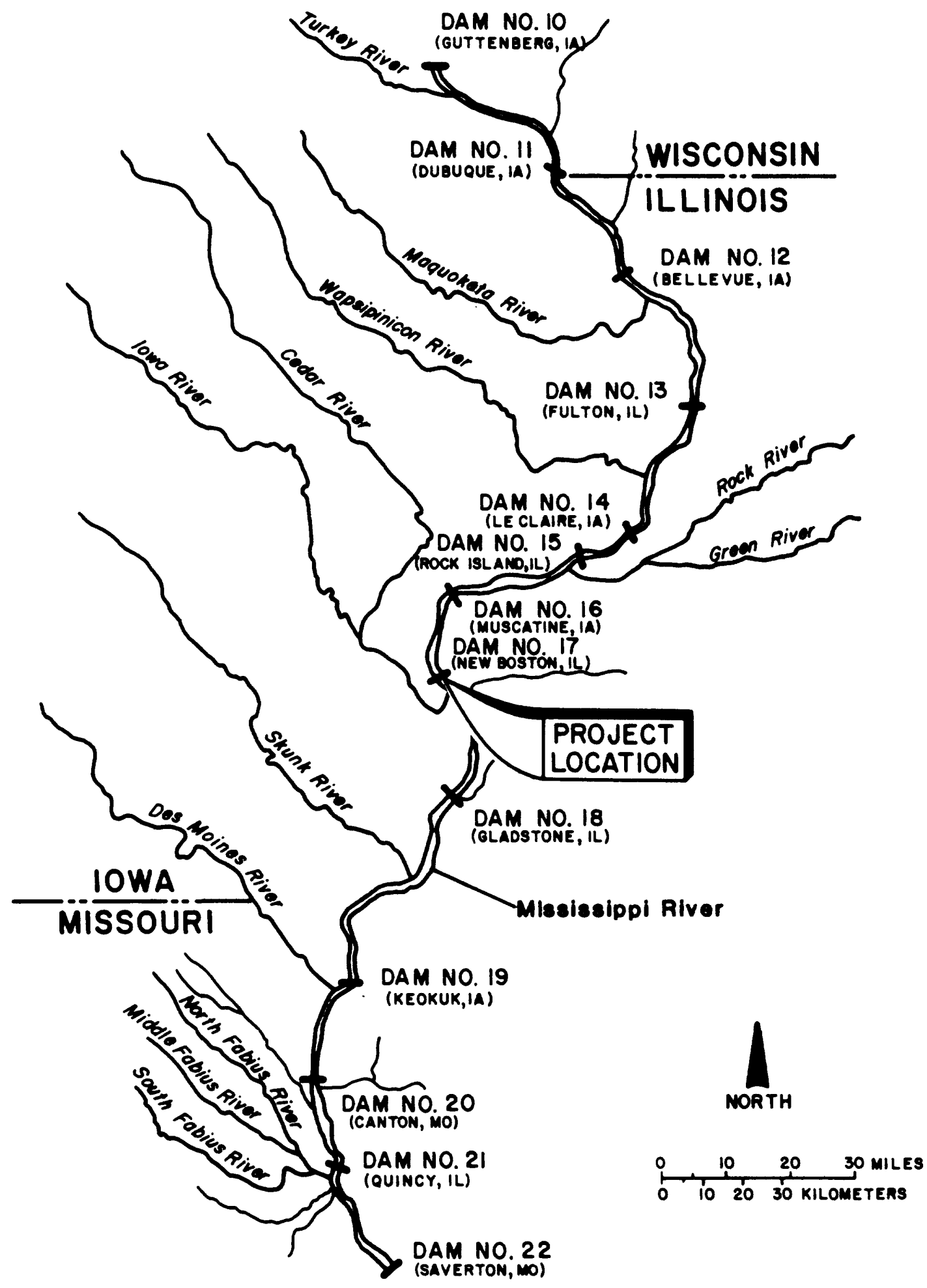

Figure 1.--Inland Waterway Navigation System of the upper Mississippi River basin (modified from U.S. Army Corps of Engineers, 1980, p1. 1). 


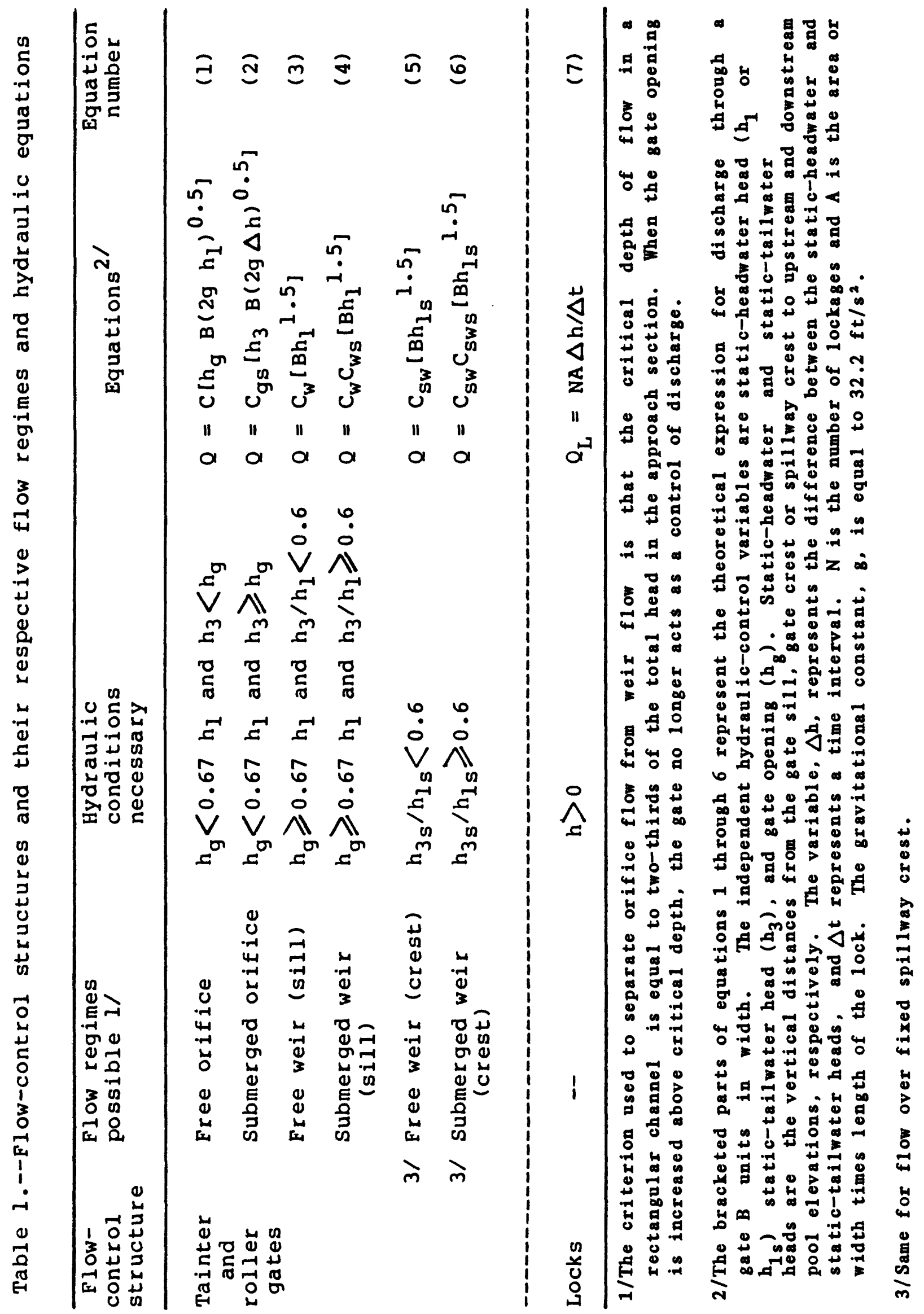


Tainter and roller gates are the only controls for which data are evaluated in this report. Coefficients for the fixed spillway are not defined. Flow through the locks can be computed by multiplying the volume of water contained in the lock times the number of lockages during a fixed period of time.

\section{DAM OPERATION}

Lock and Dam 17 contains 8 tainter gates and 3 roller gates for controlling the pool elevation upstream from the dam. Each tainter gate is 64.2 feet wide and 20 feet high and operates between the piers with 64.2 -foot clear openings. The tainter gates are of the submergible type, capable of being lowered 8 feet below the sill elevation. Each roller gate is 100 feet wide and 20 feet high and operates between piers with 100-foot clear openings. The roller gates are of the submergible type, capable of 8 feet of submergence. Four of the tainter gates, located adjacent to the lock, are separated from the remainder of the tainter gates by the three roller gates, which are situated at about mid-channel (fig. 2). Sectional views of the tainter and roller gates are shown in figure 3.

Submerged-orifice flow predominates when the control gates at Dam 17 are in operation (U.S. Army Corps of Engineers, 1980, p1. 25). Free orifice flow rarely occurs at a low-head, navigation-type structure such as Dam 17 and would not occur at this dam under normal operating conditions.

Free-weir flow at Dam 17 would occur primarily with the gates in a submerged condition with flow over the crests of the gates. The gates are operated in the submerged position in the winter when there is no commercial navigation. Submerged weir flow could occur with the gates in a submerged condition at a time of high flow in the river. However, the gates would 


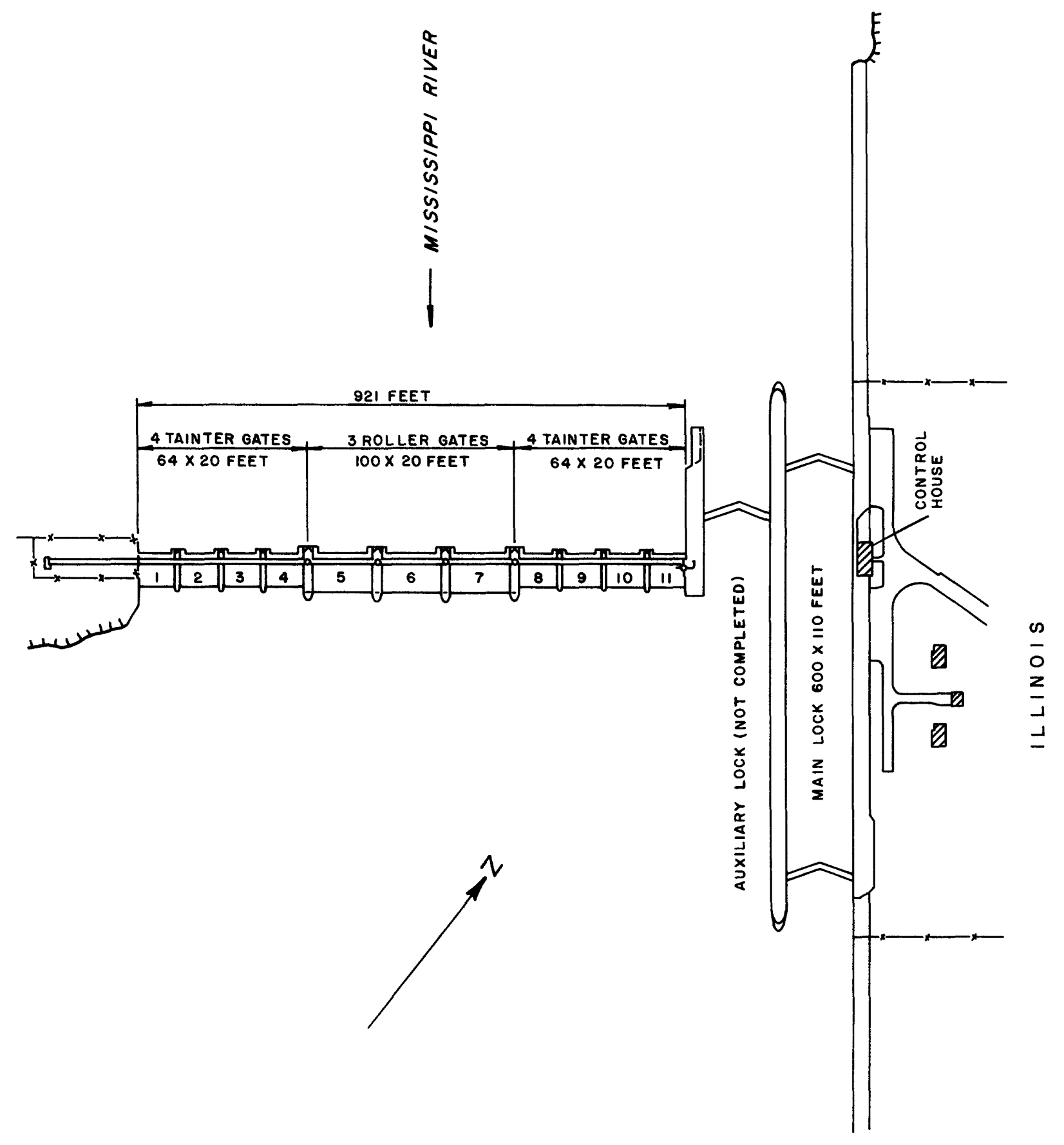

Figure 2.--Location of flow-control structures (modified from U.S. Army Corps of Engineers, 1980, p1. 2). 

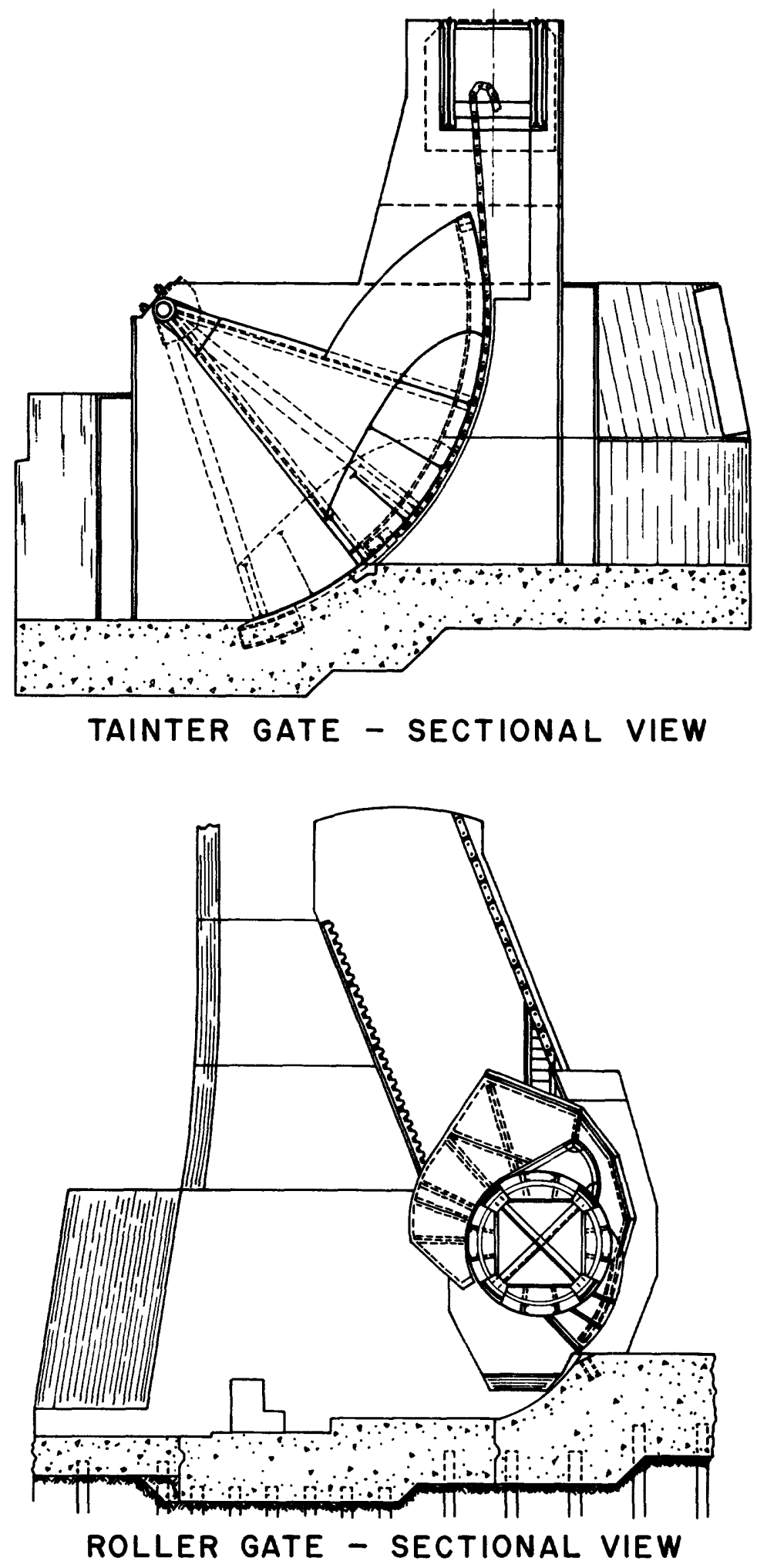

Figure 3.--Sectional views of tainter and roller gates (modified from U.S. Army Corps of Engineers, 1980, pls. 5 and 6). 
normally be raised above the water surface before submerged weir flow would occur over the gate crests. Submerged-weir flow would also occur over the gate sills with the gates raised above the water surface when the dam is out of operation. This type flow is not evaluated in this report.

Operation of the control gates for maintaining the pool elevation is based on a study (U.S. Army Corps of Engineers, 1980) conducted to determine the optimum use of the dam for river flowage, conservation interests, and towboat service. Operation "Plan A" (U.S. Army Corps of Engineers, 1980, pl. 25) was adopted and put into use in the 1940 navigation season and remains in effect. Plan "A" allows the high water levels to recede naturally until the authorized pool elevation for lower flows is reached.

Dam 17 is a run-of-the-river dam and is not operated to store water for flood control purposes. The pool is maintained between stages 8.9 and 9.4 feet when the dam is in operation. When the river is rising and the tailwater stage reaches 8.3 feet, the tainter and roller gates are raised above the water surface. During flood periods, the gates are raised out of the water allowing run-of-the-river flow to occur. During winter, when there is no commercial navigation and the pools become ice covered, the tainter and roller gates at Dam 17 are placed in the submerged position. The pool is maintained within the winter operating stage of 8.3 to 9.3 feet. 


\section{DISCHARGE AND STAGE MEASUREMENTS}

The tainter and roller gates are built with a roadway over the structures giving access to the forebays with standard current-meter measuring equipment. The discharge measurements were made from the upstream edge of the roadway which is about 20 feet upstream from the downstream edge of the tainter-gate sills and about 25 feet upstream for the roller gates. The distance of the measuring equipment from the orifice and control structure appeared to be adequate to allow accurate measurements to be made. Some velocity measurements were made to define vertical velocity curves and to verify the standard 0.2 and 0.8 method of velocity observation. The measurements were made with equipment normally used for measuring large streams. Velocity was measured using a type AA current meter suspended with Columbus-type sounding weights (50-150 pounds) from a collapsible crane (Rantz and others, 1982). A cable stay was used on top of the upstream piers to prevent the meter from running downstream into the gate orifice when the gates were opened 5 feet or more.

A total of 43 measurements of discharge ranging from 1,080 to 17,300 cubic feet per second in a gate were made in the forebays of the tainter and roller gate structures of Lock and Dam 17. Discharge coefficients for all the gates of the same design could be developed from measurements on a single gate. However, to insure greater accuracy because of the fluctuations of the pool and tailwater during the measurements and to account for variations in entrance and exit conditions, several gates were selected for calibration. Discharge was measured at least once through all but three $(1,9$ and 11$)$ of the gate bays for submerged orifice flow. Only tainter gate numbers 3 and 8 and roller gate number 6 were measured with the gates in a free weir flow position. The results of these measurements are listed in table 2 . 
Table 2.--Summary of current-meter discharge measurements and hydraulic-control data for control gates at Mississippi River Lock and Dam 17

\begin{tabular}{|c|c|c|c|c|c|c|c|c|c|c|}
\hline $\begin{array}{c}\text { Gate } \\
\text { number }\end{array}$ & Date & $\begin{array}{l}\text { Head- } \\
\text { water } \\
\text { head } \\
\text { h1 } 1 / \\
\text { (feet) }\end{array}$ & $\begin{array}{l}\text { Tail- } \\
\text { water } \\
\text { head } \\
h_{3} 2 / \\
\text { (feet) }\end{array}$ & $\begin{array}{c}\text { Gage } \\
\text { reading } \\
\text { G } \\
(\text { feet) }\end{array}$ & $\begin{array}{l}\text { Gate } \\
\text { opening } \\
\text { h } \\
\text { (feet) }\end{array}$ & $\begin{array}{l}\text { Dis- } \\
\text { charge } \\
\left(\mathrm{ft}^{3} / \mathrm{s}\right)\end{array}$ & $\begin{array}{l}\text { Deviation } \\
\text { from } \\
\text { rating } \\
\text { (percent) }\end{array}$ & $\begin{array}{c}\text { Sub- } \\
\text { mer- } \\
\text { gence } \\
\text { ratio } \\
\left(h_{3} / h_{g}\right)\end{array}$ & $\begin{array}{l}\text { Flow } \\
\text { coef- } \\
\text { ficent } \\
\left(C_{g s}\right)\end{array}$ & $\begin{array}{l}\text { Flow } 3 / \\
\text { regime }\end{array}$ \\
\hline $\begin{array}{l}2 \\
2 \\
2\end{array}$ & $\begin{array}{l}8-28-86 \\
8-28-86 \\
8-28-86\end{array}$ & $\begin{array}{l}20.06 \\
20.07 \\
20.08\end{array}$ & $\begin{array}{l}18.54 \\
18.53 \\
18.53\end{array}$ & $\begin{array}{l}7.00 \\
8.00 \\
9.00\end{array}$ & $\begin{array}{l}7.04 \\
8.07 \\
9.04\end{array}$ & $\begin{array}{l}3,920 \\
4,540 \\
5,170\end{array}$ & $\begin{array}{l}-1.3 \\
-1.9 \\
-1.5\end{array}$ & $\begin{array}{l}2.63 \\
2.30 \\
2.05\end{array}$ & $\begin{array}{l}0.333 \\
0.384 \\
0.435\end{array}$ & $\begin{array}{l}\text { so } \\
\text { so } \\
\text { so }\end{array}$ \\
\hline $\begin{array}{l}3 \\
3 \\
3 \\
3 \\
3 \\
3 \\
3\end{array}$ & $\begin{array}{l}2-02-87 \\
2-02-87 \\
3-05-87 \\
2-02-87 \\
2-02-87 \\
2-02-87 \\
2-03-87\end{array}$ & $\begin{array}{l}19.69 \\
19.68 \\
19.97 \\
19.74 \\
19.70 \\
19.70 \\
19.73\end{array}$ & $\begin{array}{l}16.22 \\
16.22 \\
16.61 \\
16.22 \\
16.22 \\
16.22 \\
16.16\end{array}$ & $\begin{array}{l}3.00 \\
4.00 \\
4.00 \\
5.00 \\
3.00 \mathrm{~s} \\
4.00 \mathrm{~s} \\
5.00 \mathrm{~s}\end{array}$ & $\begin{array}{l}2.92 \\
3.91 \\
3.88 \\
4.91 \\
2.30 \mathrm{~b} \\
3.30 \mathrm{~b} \\
4.30 \mathrm{~b}\end{array}$ & $\begin{array}{l}2,300 \\
3,070 \\
3,320 \\
3,910 \\
1,180 \\
1,790 \\
2,480\end{array}$ & $\begin{aligned}- & 1.7 \\
- & 4.4 \\
+ & 6.1 \\
- & 5.6 \\
+ & 4.4 \\
+ & 1.1 \\
& 0\end{aligned}$ & $\begin{array}{l}5.55 \\
4.15 \\
4.28 \\
3.30\end{array}$ & $\begin{array}{l}0.148 \\
0.198 \\
0.212 \\
0.250 \\
5.27 \mathrm{w} \\
4.65 \mathrm{w} \\
4.33 \mathrm{w}\end{array}$ & $\begin{array}{l}\text { SO } \\
\text { SO } \\
\text { SO } \\
\text { SO } \\
\text { FW } \\
\text { FW } \\
\text { FW }\end{array}$ \\
\hline $\begin{array}{l}4 \\
4 \\
4 \\
4 \\
4\end{array}$ & $\begin{array}{l}2-02-87 \\
3-05-87 \\
8-28-86 \\
8-28-86 \\
8-28-86\end{array}$ & $\begin{array}{l}19.72 \\
19.96 \\
20.04 \\
20.04 \\
20.04\end{array}$ & $\begin{array}{l}16.22 \\
16.63 \\
18.53 \\
18.54 \\
18.54\end{array}$ & $\begin{array}{l}3.00 \\
4.00 \\
7.00 \\
8.00 \\
9.00\end{array}$ & $\begin{array}{l}3.03 \\
3.93 \\
7.03 \\
8.06 \\
9.06\end{array}$ & $\begin{array}{l}2,420 \\
3,320 \\
3,760 \\
4,470 \\
5,090\end{array}$ & $\begin{array}{l}-1.2 \\
+5.1 \\
-4.8 \\
-2.0 \\
-1.7\end{array}$ & $\begin{array}{l}5.35 \\
4.23 \\
2.64 \\
2.30 \\
2.05\end{array}$ & $\begin{array}{l}0.155 \\
0.212 \\
0.321 \\
0.382 \\
0.435\end{array}$ & $\begin{array}{l}\text { so } \\
\text { so } \\
\text { so } \\
\text { so } \\
\text { so }\end{array}$ \\
\hline 5 & $3-05-87$ & 19.95 & 16.65 & 4.00 & & 4,340 & -0.7 & 4.16 & 0.179 & so \\
\hline $\begin{array}{l}6 \\
6 \\
6 \\
6 \\
6 \\
6 \\
6 \\
6 \\
6 \\
6 \\
6\end{array}$ & $\begin{array}{l}3-05-87 \\
3-05-87 \\
3-05-87 \\
8-27-86 \\
8-27-86 \\
8-27-86 \\
8-27-86 \\
8-27-86 \\
8-27-86 \\
3-05-87 \\
3-05-87\end{array}$ & $\begin{array}{l}19.95 \\
19.95 \\
19.95 \\
20.21 \\
20.18 \\
20.12 \\
20.15 \\
20.21 \\
20.21 \\
19.96 \\
19.96\end{array}$ & $\begin{array}{l}16.64 \\
16.64 \\
16.65 \\
17.87 \\
17.87 \\
17.85 \\
17.97 \\
17.95 \\
17.95 \\
16.63 \\
16.63\end{array}$ & $\begin{array}{c}3.00 \\
4.00 \\
5.00 \\
7.00 \\
8.00 \\
9.00 \\
9.00 \\
9.50 \\
10.00 \\
2.00 \mathrm{~s} \\
4.00 \mathrm{~s}\end{array}$ & $\begin{array}{l}2.00 \mathrm{~b} \\
4.00 \mathrm{~b}\end{array}$ & $\begin{array}{r}3,470 \\
4,470 \\
5,350 \\
6,470 \\
8,540 \\
14,300 \\
13,600 \\
16,000 \\
17,300 \\
1,790 \\
3,660\end{array}$ & $\begin{array}{l}+5.8 \\
+2.3 \\
-2.0 \\
+0.5 \\
-4.5 \\
+2.9 \\
+1.5 \\
-4.8 \\
-15.2 \\
+0.6 \\
-0.3\end{array}$ & $\begin{array}{l}5.55 \\
4.16 \\
3.33 \\
2.55 \\
2.25 \\
1.98 \\
1.99 \\
1.89 \\
1.80\end{array}$ & $\begin{array}{l}0.143 \\
0.184 \\
0.221 \\
0.295 \\
0.392 \\
0.663 \\
0.639 \\
0.739 \\
0.799 \\
6.33 \mathrm{w} \\
4.58 \mathrm{w}\end{array}$ & $\begin{array}{l}\text { so } \\
\text { so } \\
\text { so } \\
\text { so } \\
\text { so } \\
\text { so } \\
\text { so } \\
\text { SO } \\
\text { SO } \\
\text { FW } \\
\text { FW }\end{array}$ \\
\hline 7 & $3-05-87$ & 19.95 & 16.65 & 4.00 & & 4,150 & -5.0 & 4.16 & 0.171 & so \\
\hline $\begin{array}{l}8 \\
8 \\
8 \\
8 \\
8 \\
8 \\
8 \\
8 \\
8 \\
8\end{array}$ & $\begin{array}{l}2-02-87 \\
2-02-87 \\
3-05-87 \\
2-02-87 \\
8-28-86 \\
8-28-86 \\
8-28-86 \\
2-02-87 \\
2-02-87 \\
2-02-87\end{array}$ & $\begin{array}{l}19.68 \\
19.70 \\
19.95 \\
19.75 \\
20.04 \\
20.04 \\
20.04 \\
19.69 \\
19.70 \\
19.70\end{array}$ & $\begin{array}{l}16.22 \\
16.22 \\
16.65 \\
16.22 \\
18.52 \\
18.52 \\
18.52 \\
16.22 \\
16.22 \\
16.20\end{array}$ & $\begin{array}{l}3.00 \\
4.00 \\
4.00 \\
5.00 \\
7.00 \\
8.00 \\
9.00 \\
3.00 \mathrm{~s} \\
4.00 \mathrm{~s} \\
5.00 \mathrm{~s}\end{array}$ & $\begin{array}{l}3.02 \\
4.00 \\
3.99 \\
5.01 \\
7.02 \\
8.02 \\
8.96 \\
2.29 b \\
3.30 b \\
4.30 b\end{array}$ & $\begin{array}{l}2,460 \\
3,160 \\
3,230 \\
4,060 \\
4,060 \\
4,640 \\
5,280 \\
1,080 \\
1,590 \\
2,300\end{array}$ & $\begin{array}{l}+1.2 \\
-4.2 \\
+1.2 \\
-4.0 \\
+2.5 \\
+1.5 \\
+2.5 \\
-4.4 \\
-10.2 \\
-7.3\end{array}$ & $\begin{array}{l}5.37 \\
4.06 \\
4.17 \\
3.24 \\
2.64 \\
2.31 \\
2.07\end{array}$ & $\begin{array}{l}0.158 \\
0.203 \\
0.207 \\
0.259 \\
0.345 \\
0.395 \\
0.449 \\
4.85 w \\
4.13 w \\
4.02 w\end{array}$ & $\begin{array}{l}\text { so } \\
\text { so } \\
\text { so } \\
\text { SO } \\
\text { so } \\
\text { sO } \\
\text { SO } \\
\text { FW } \\
\text { FW } \\
\text { FW }\end{array}$ \\
\hline $\begin{array}{l}10 \\
10 \\
10 \\
10 \\
10\end{array}$ & $\begin{array}{l}2-02-87 \\
3-05-87 \\
8-27-86 \\
8-27-86 \\
8-27-86\end{array}$ & $\begin{array}{l}19.70 \\
19.95 \\
20.08 \\
19.98 \\
20.01\end{array}$ & $\begin{array}{l}16.22 \\
16.64 \\
17.87 \\
17.87 \\
17.87\end{array}$ & $\begin{array}{l}3.00 \\
4.00 \\
7.00 \\
8.00 \\
9.00\end{array}$ & $\begin{array}{l}3.06 \\
4.04 \\
6.96 \\
7.92 \\
8.87\end{array}$ & $\begin{array}{l}2,380 \\
3,220 \\
4,660 \\
5,370 \\
6,170\end{array}$ & $\begin{array}{l}-3.6 \\
-0.6 \\
-1.7 \\
+0.8 \\
+1.8\end{array}$ & $\begin{array}{l}5.30 \\
4.12 \\
2.57 \\
2.26 \\
2.01\end{array}$ & $\begin{array}{l}0.153 \\
0.207 \\
0.341 \\
0.402 \\
0.458\end{array}$ & $\begin{array}{l}\text { so } \\
\text { so } \\
\text { so } \\
\text { so } \\
\text { so }\end{array}$ \\
\hline
\end{tabular}

I/ $h_{1}=$ Pool stage +10.70 feet.

2/ $h_{3}=$ Tailwater $(T / W)$ stage +10.70 feet.

$3 /$ Só designates submerged-orifice flow. FW designates free-weir flow.

b Computed headwater, h, over gate crest.

$s$ Gate in submerged position

$w$ Coefficient, $C_{s w}$, for free-weir flow. 
The control gates were submerged, in the winter operating position, with free-weir flow over the gate crests when the discharge measurements of February 2, 1987, were made. When selected gates were raised for making discharge measurements at the submerged-orifice flow position, large ripples were observed in the approach to the forebays of the gates. These large ripples were probably caused by a sand bar that had accumulated in the approach section upstream from the gates over the winter period while the gates were submerged. The discharge measurements made this day at the 4- and 5-foot gate openings plot about 5 percent to the left of the ratings (fig. 7 ). This discrepancy is being attributed to obstructed flow conditions at the approach to the forebays of the gates while the gates were being measured. Ripples were not observed during discharge measurements made on March 5, 1987, and these measurements plot either on or to the right of the rating curve defined for the pool and tailwater conditions at which they were made.

Leakage, which is common to submergible gates because of the clearance provided between the gate and sill for lowering the gates, was not separately determined. The flow attributable to leakage is included in the discharge measurements and in the discharge equations.

The concurrent pool and tailwater stages for the measurements were obtained from the gages in the operations control building. The staticheadwater head $\left(h_{1}\right)$ and static-tailwater head $\left(h_{3}\right)$ referenced to the gate sill are obtained by adding 10.70 feet to the stage readings. The stages can be referenced to sea level by adding the zero gage datum, 526.70 feet (1912 adjustment), to the stages.

The gate-opening settings for the tainter gates were read from the gateposition indicator gages on the tainter gates and those for the roller gates 
were read from the gate-position indicator marks on the operating machinery. For submerged orifice flow, the gate-position gages indicate the gate opening between the gate sill and the bottom of the gate. For free-weir flow, the gate-position gages indicate the static-headwater head over the crest of the gate at the normal operating pool stage of 9.30 feet. Subsequently, the gateposition indicator gage readings will be referred to as "gage readings" and the pool and tailwater gage readings will be referred to as "stages".

\section{TAINTER-GATE FLOW}

\section{Computation of Gate Opening}

The gate opening, $h_{g}$, is the most important variable in calibrating the flow through tainter gates. In most cases, the gate opening cannot be measured directly in the field during operation of the structure. Therefore, the gate opening is computed indirectly using pertinent geometric properties of the gates and direct measurements of the elevation of a selected reference point on each gate. Dimensions of gate-structure members that cannot be measured on the gate are obtained from the construction plans. These include the gate radius, $R$, and the included angle, $\theta$, of the gate structure (fig. 4).

The reference point (R.P.) established for computing the gate opening, $h_{g}$, for the tainter gates on Dam 17 is the top of a rivet on an angle iron connecting the top gate arm to the arched crest of the gate structure. The rivet is the second, of four rivets, from the pier and is 0.5 foot below the top edge of the gate arm (fig. 4). The R.P. is 17.79 feet from the trunnion centerline and is the same for all the gates. The elevation of each R.P. and the trunnion centerlines was determined by levels from established benchmarks 


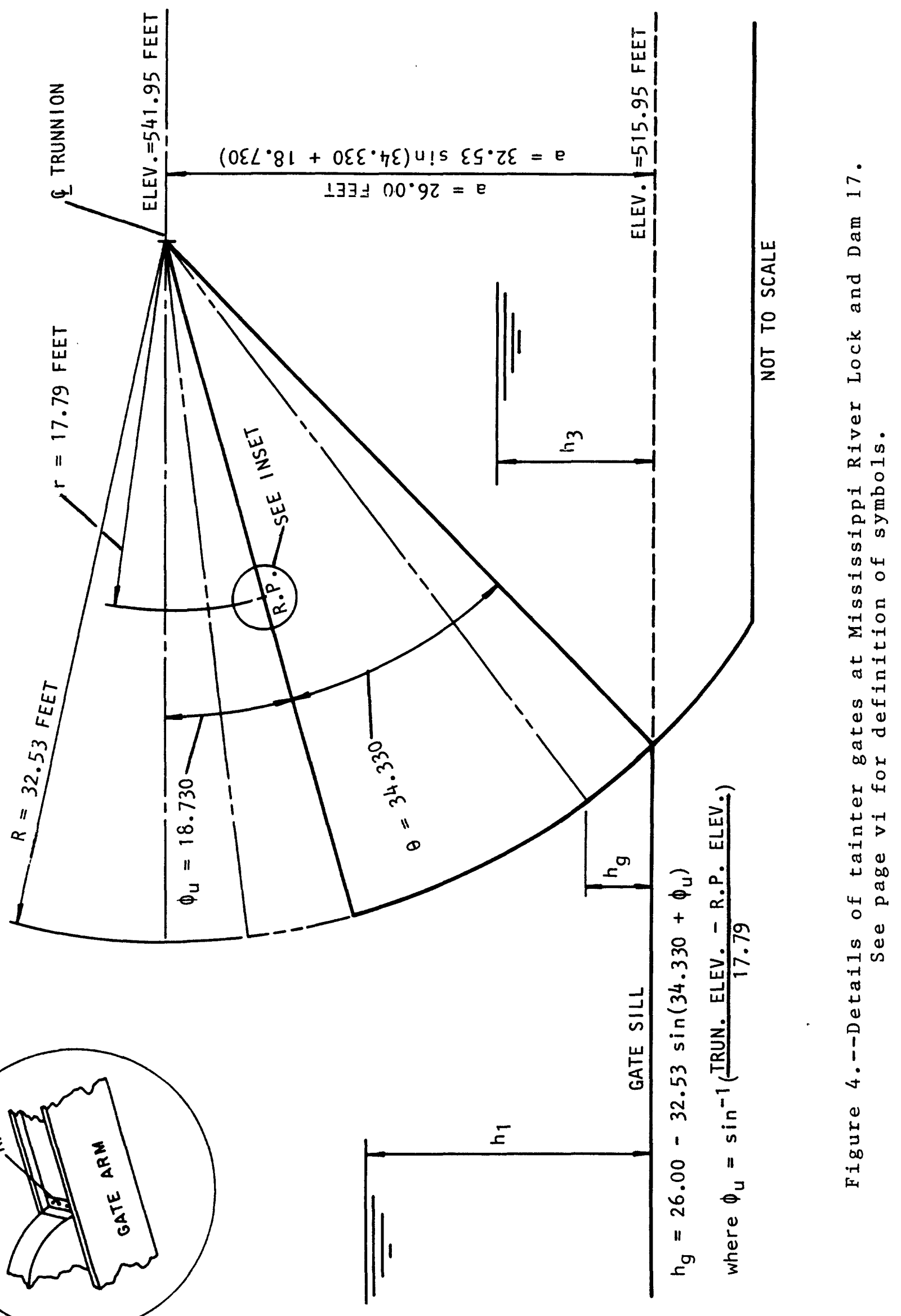


on the piers between the gates (U.S. Army Corps of Engineers, 1974). The vertical gate opening, $h_{g}$, is computed from the equation:

$$
\begin{gathered}
h_{g}=26.00-32.53 \sin \left(34.33+\phi_{u}\right) \\
\text { where } \phi_{u}=\sin ^{-1}[(\text { Trunnion elev. - R.P. elev. }) / 17.79]
\end{gathered}
$$

The terms in the equation are graphically displayed in figure 4 . The average elevation of the trunnion centerlines was found at 541.95 feet with variations from 541.91 to 541.99 feet.

Because the gates are submergible, there is no way to determine at what position the gates are in a "closed" position. Defining the relation between the "true" gate opening $\left(h_{g}\right)$ and the gage indicator is relatively straight forward for non-submergible gates, such as those for Lock and Dam 14, where $\mathrm{h}_{\mathrm{g}}=0$ can be determined by closing the gate. (With the gates at Dam 14 in a closed position $\left(h_{g}=0\right)$, computations of the gate openings $\left(h_{g}\right)$ erroneously indicate that the gates are open an average of 0.19 foot. This 0.19 foot error was eliminated by adjusting the included angle of the gate). The decision was arbitrarily made to adjust the included angle of the dam 17 tainter gate structure so that the average computed gate openings $\left(h_{g}\right)$ would be the same as the gage-indicator readings. The resulting angle of the gate structure is 34.33 degrees (fig. 4). Note that the angle of 34.33 degrees is not the full included angle of the gate structure because the R.P. is 0.5 foot below the top edge of the upper gate arm. The advantage of using this approach is that the discharge for the average gate openings can be computed using the gageindicator readings directly. The adjusted $h_{g}$ values for a 3.00 foot gate opening range from 2.90 to 3.08 feet. Corrections (e) for the individual gates and the relation of the gate openings $\left(h_{g}\right)$ to the 3.00 -foot gage-indicator setting are shown in figure 5 . 

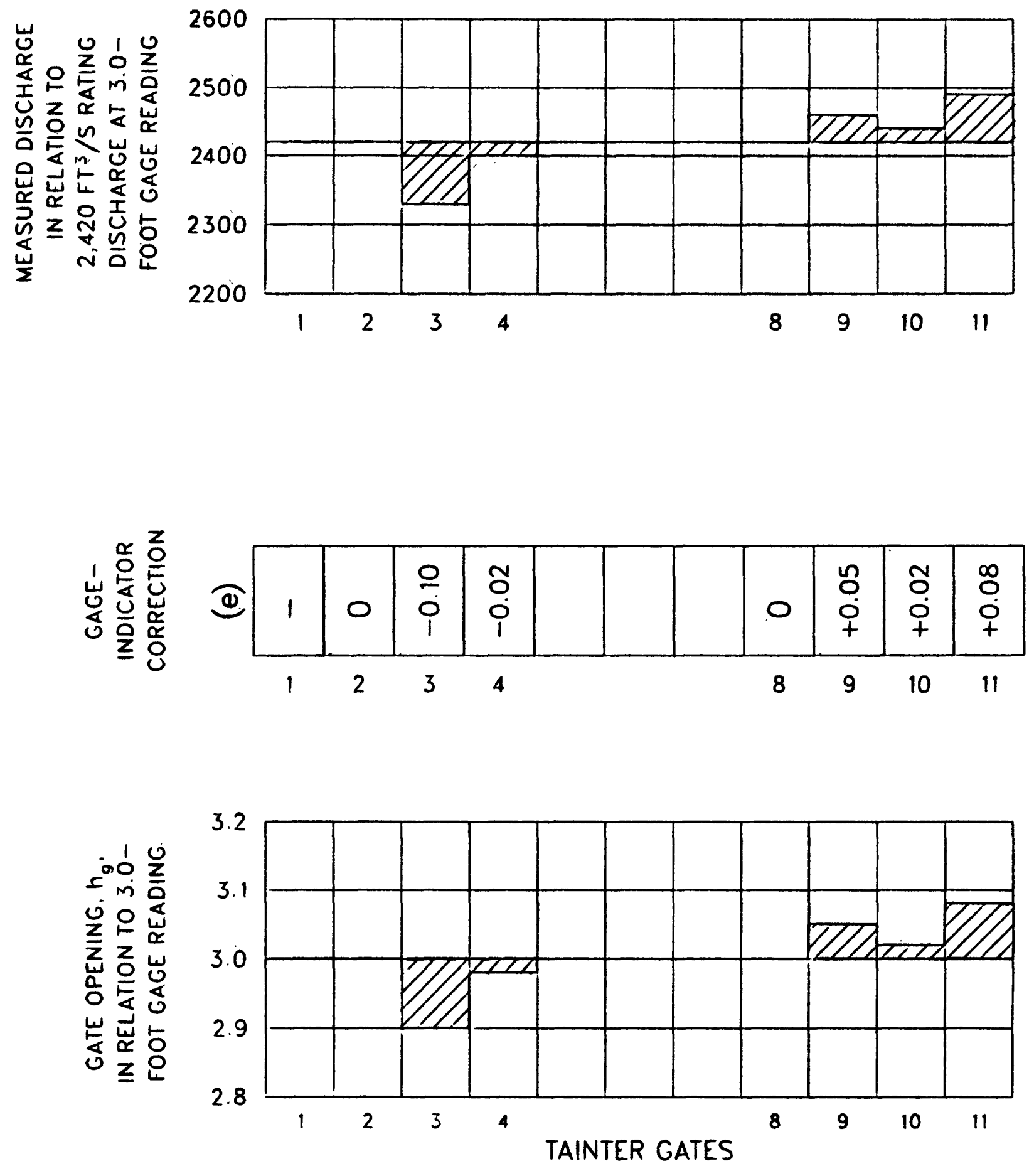

Figure 5.--Gage-indicator corrections and comparison of gate openings and discharges at 3.0 feet gage-indicator settings for tainter gates on Mississippi river Lock and Dam 17. 
A gage-indicator error of 0.10 foot will result in about a 5-percent deviation in discharge from the rating discharge at the 2.00 foot gage setting. This deviation from the rating discharge increases with lower gage settings (about 10 percent at the 1.00 -foot gage setting) and decreases at higher gage settings (about 3 percent at the 4.00-foot gage setting). The deviation of discharge from the rating discharge for the individual gates could be minimized by adjusting the gage indicators to more nearly reflect the computed gate opening, $h_{g}$.

\section{Submerged-Orifice Flow Coefficients}

Discharge coefficients for submerged orifice flow were computed by solving equation 2 in table 1 for $C_{g s}$ using the results of the discharge measurements (table 2) that were made with the gates in submerged-orifice flow conditions. The submerged-orifice flow coefficients, $\mathrm{C}_{\mathrm{gs}}$, are listed in table 2 and a graph defining the relationship of $\mathrm{C}_{\mathrm{gs}}$ to the orifice-submergence ratio is shown in figure 6 . The resulting equation, relating the submerged-orifice coefficient, $\mathrm{C}_{g s}$, to the orifice submergence ratio, $\mathrm{h}_{3} / \mathrm{h}_{\mathrm{g}}$, is:

$$
C_{g s}=0.96\left(h_{3} / h_{g}\right)^{-1.08}
$$




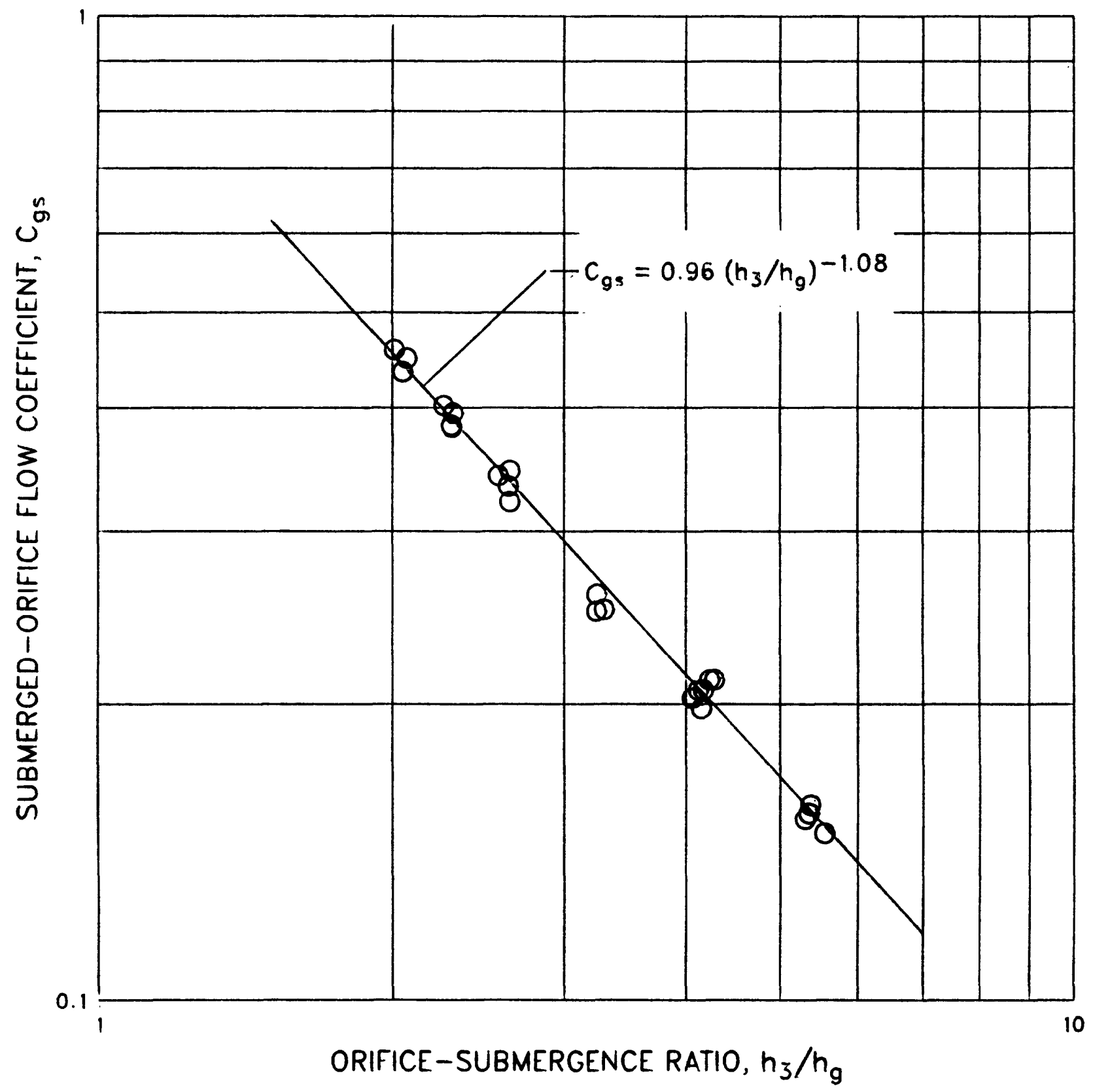

rigure 6.--Relation between submerged-orifice flow coefficient and orifice-submergence ratio for Lock and Dam 17 tainter gates. 


\section{Submerged-Orifice Discharge Equation}

An equation for computing discharge for submerged-orifice flow in the tainter gate bays was developed using the submerged-orifice equation (2) and substituting equation 9 for the submerged-orifice coefficient, $\mathrm{C}_{\mathrm{gs}} \cdot$ The resulting equation relating the discharge (Q) to the orifice-submergence ratio $\left(h_{3} / h_{g}\right)$ and the static-headloss $\left(h_{1}-h_{3}\right)$ is:

$$
Q=494 h_{3}\left(h_{3} / h_{g}\right)^{-1.08}\left(h_{1}-h_{3}\right)^{0.5}
$$

where $h_{g}=$ gage reading + the individual gage-indicator correction (e) shown in figure 5 (the average correction, e, for all the tainter gage indicators is $0), h_{3}=$ the tailwater stage plus 10.70 feet and $h_{1}-h_{3}=$ the difference between the pool and tailwater stages.

The relation of the current-meter discharge measurements made at the tainter gates on February 2, 1987, to the discharge curve defined by equation 10 is shown in figure 7. The measurements at the 4- and 5-foot stages plot about 5 percent to the left of the curve because of the sand obstruction in the approach cross section as explained earlier in the report. 


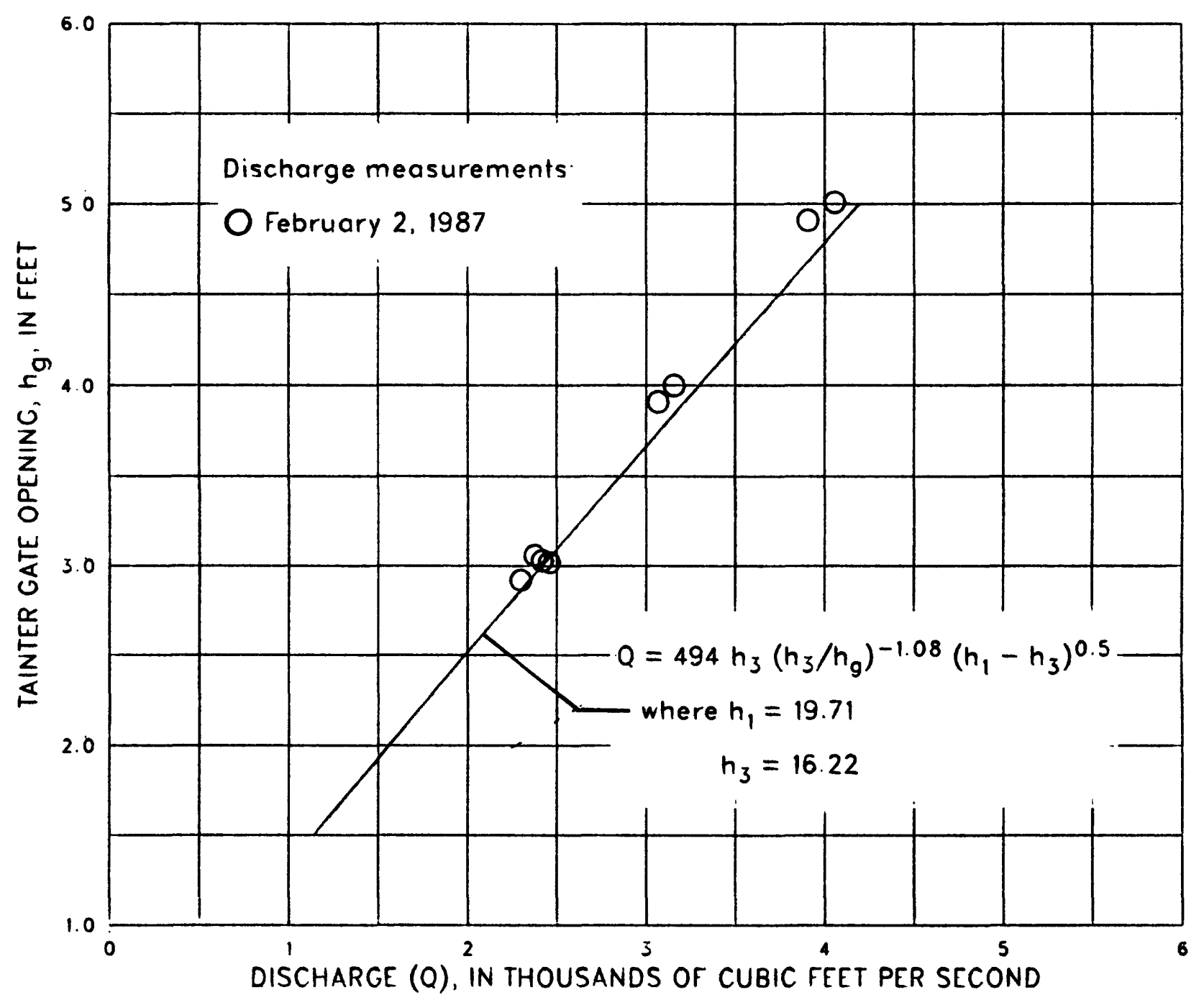

Figure 7.--Comparison of current-meter discharge measurements of February 2, 1987, to rating curves for tainter gates at Mississippi River Lock and Dam 17. 


\section{Free-Weir Flow Coefficients}

Discharge coefficients for free-weir flow for tainter gates 3 and 8 were computed by solving equation 5 in table 1 for $\mathrm{C}_{\mathrm{sw}}$ using the results of the discharge measurements (table 2) that were made with the gate in a submerged position. The free-weir coefficients, $\mathrm{C}_{\mathrm{sw}}$, are 1 isted in table 2 and a graph defining the relationship of $\mathrm{C}_{\mathrm{sw}}$ to the static-headwater head $\left(\mathrm{h}_{1 \mathrm{~s}}\right)$ over the gate crest is shown in figure 8 . The resulting equation, relating the freeweir coefficient, $\mathrm{C}_{\mathbf{S w}}$, to the static-headwater head, $\mathrm{h}_{1 \mathrm{~s}}$, is:

$$
c_{\text {sw }}=3.6\left(h_{1 s}\right)^{-0.86}+3.3
$$

where $\mathrm{h}_{1 \mathrm{~s}}=$ gage reading $-0.40+($ pool stage -9.30$)$. Also shown in figure 8 are the coefficients for Locks and Dams 11, 12 and 13. These coefficients were used to corroborate the coefficient-headwater relation for Lock and Dam 17. The -0.40 correction to the gage-indicator readings was derived from the observed pool stage at the point of zero flow over the gate crests for gates 4, 8 and 10 and elevations of the R.P. taken at each of the gate settings when a measurement of discharge was made. The correction to the gate 3 gage readings were only about one-half of that found for gates 4,8 and 10 . 


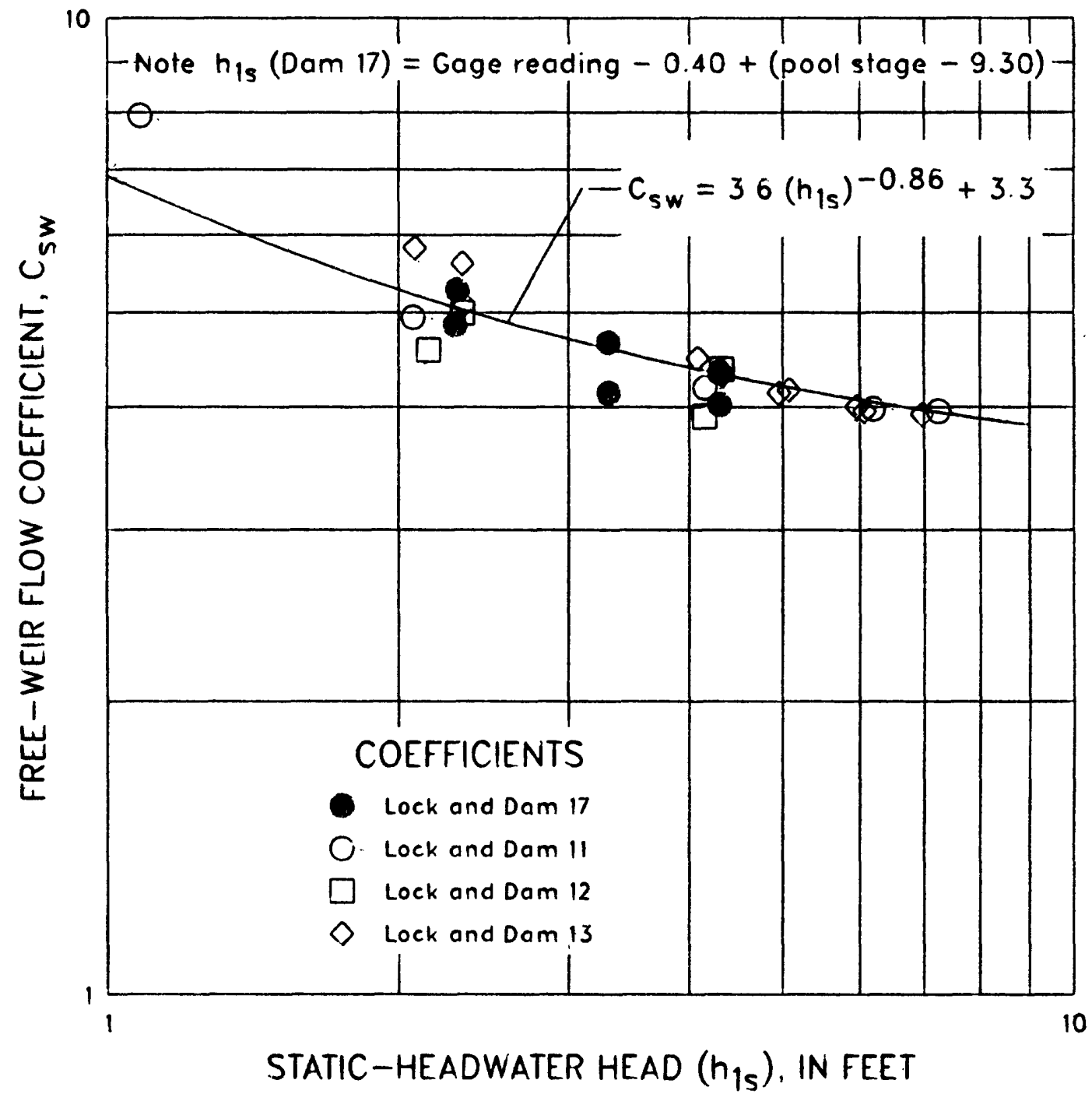

Figure 8.--Relation between free-weir flow coefficient and staticheadwater head for tainter gates in submerged position for Lock and Dam 17. 


\section{Free-Weir Discharge Equation}

An equation for computing free-weir flow in the tainter gates was developed using the free-weir flow equation (5) and substituting equation 11 for the free-weir coefficient, $\mathrm{C}_{\mathrm{sw}}$. The resulting equation, graphically illustrated in figure 9, relating the discharge (Q) to the static-headwater $\left(\mathrm{h}_{1 \mathrm{~s}}\right)$ over the gate crest is:

$$
Q=212\left(1.09 h_{1 s} 0.64+h_{1 s}^{1.50}\right)
$$

where $h_{1 s}$ is as defined for equation 11 above. Also shown in figure 9 are the discharge measurements made at Locks and Dams 11, 12 and 13. For comparison, however, the discharges for the measurements at Lock and Dam 11 were adjusted from the 60.0 feet tainter gate width to the 64.2 feet tainter gate width of the Lock and Dam 17 gates. These measurements were used to corroborate the rating development for Lock and Dam 17. 


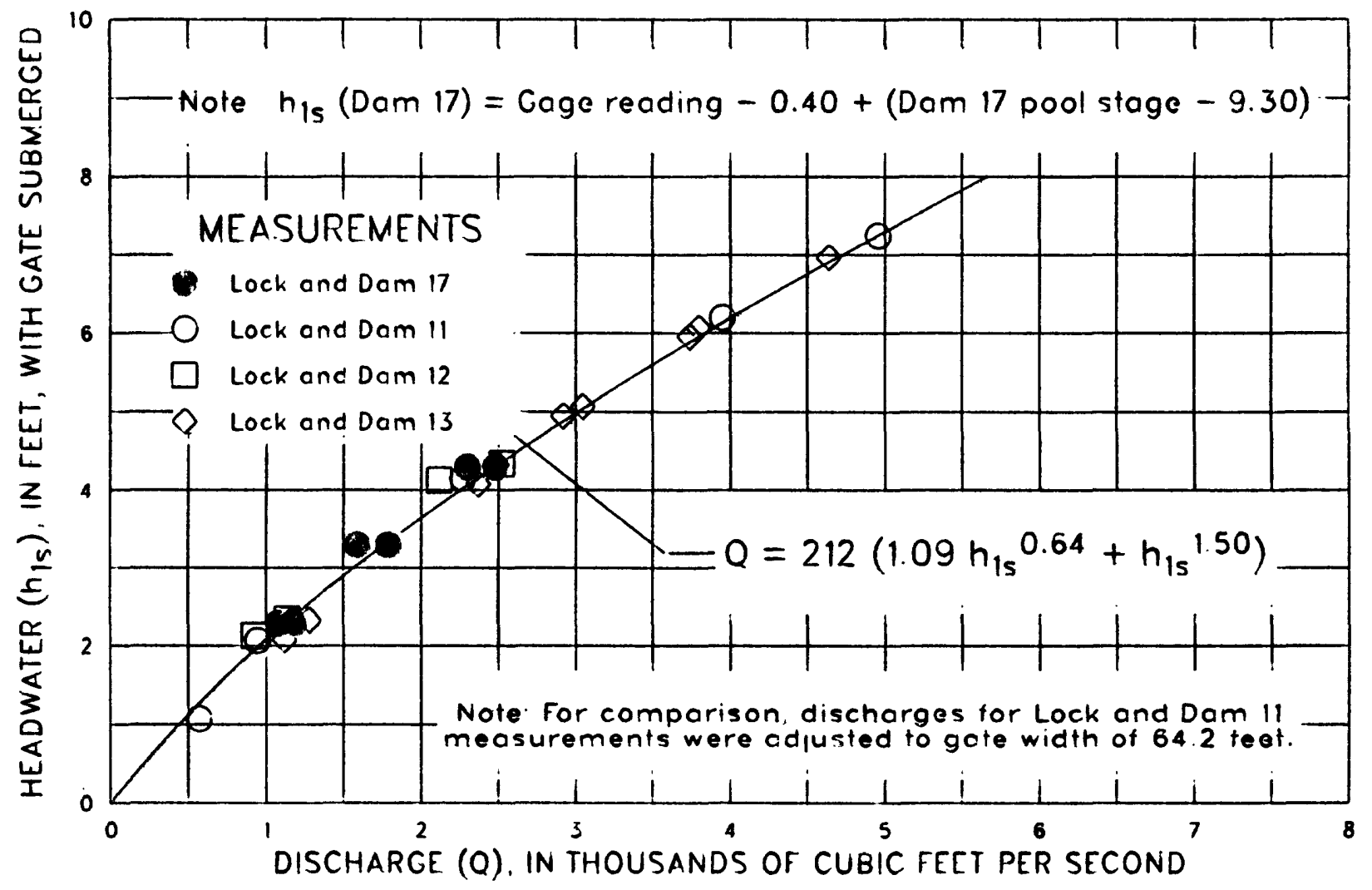

Figure 9.--Relation between discharge and headwater for free-weir flow for tainter gates in submerged position for Lock and Dam 17. 


\section{ROLLER-GATE FLOW}

\section{Gate Opening}

The gate-opening indicator marks for the roller gates are an integral part of the operating machinery of the gate. These indicators presumably give a fairly accurate reading of the gate opening. A method for measuring the actual gate openings was not developed.

\section{Submerged-Orifice Flow Coefficient}

Discharge coefficients for submerged-orifice flow for Dam 17 were used to define the relation with the orifice-submergence ratio, $h_{3} / h_{g}$. The coefficients were computed by solving equation 2 in tatle 1 for $\mathrm{C}_{\mathrm{gs}}$ using the results of the discharge measurements (table 2) that were made under submerged-orifice flow conditions.

The relation of the submerged-orifice flow coefficient, $\mathrm{C}_{\mathrm{gs}}$, to the orifice-submergence ratio, $h_{3} / h_{g}$, for the roller gates on Dam 17 is shown in figure 10. The break in the relation occurs at a point when the gate is open greater than 7 feet and the submergence ratio is less than 2.4 for the Dam 17 roller gates. The break in the relationship apparently occurs when control of flow of the roller gate transfers from the lower apron (appendage to the drum) on the roller to the drum of the gate structure. The control positions of the roller gate are illustrated in figure 11 and show that the effective gate opening increases significantly when control transfers from the apron to the drum when the gate is opened more than 7.0 feet. 


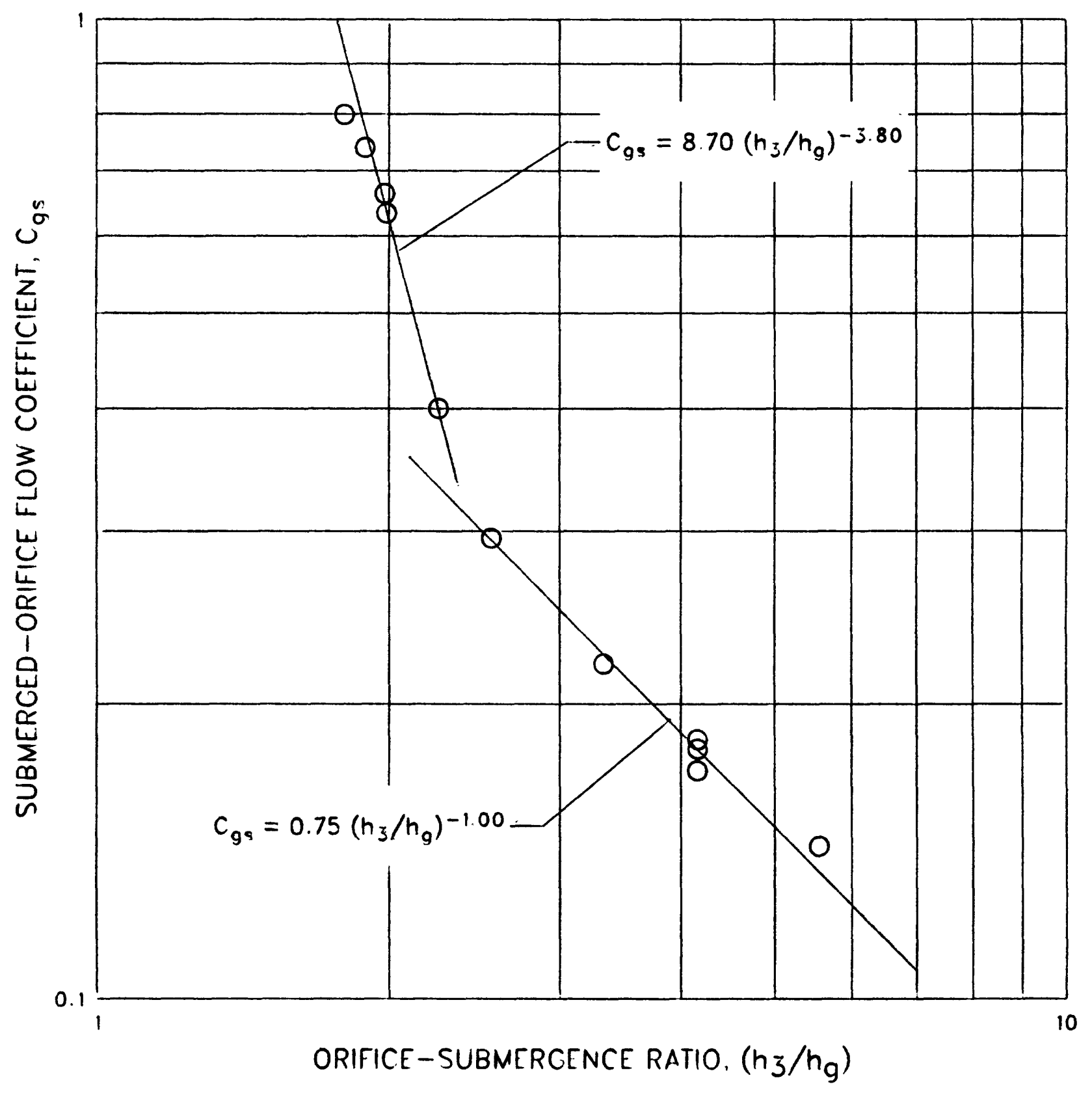

rigure 10.--Relation between submerged-orifice flow coefficient and orifice-submergence ratio for Lock and Dam 17 roller gates 


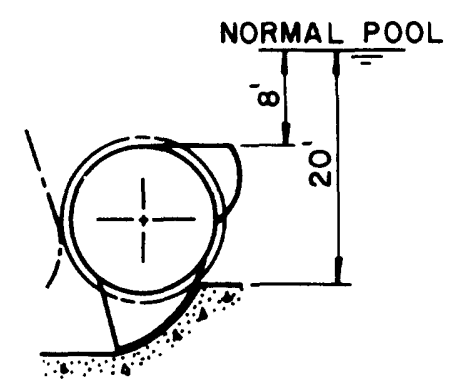

GATE CREST $12 \mathrm{FT}$.

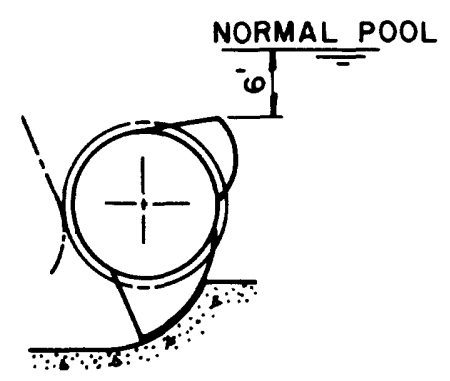

GATE CREST $14 \mathrm{FT}$.

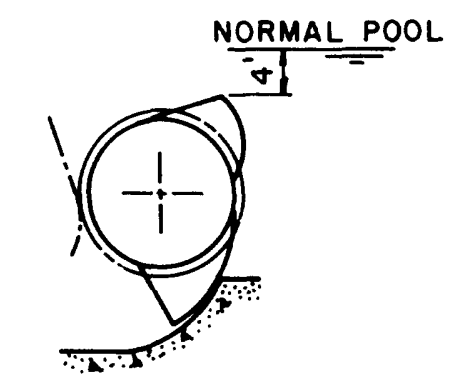

GATE CREST 16FT.

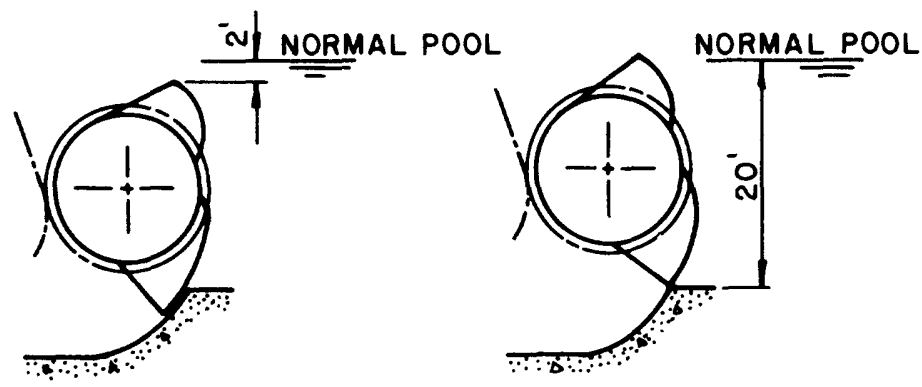

GATE CREST $18 \mathrm{FT}$. GATE CREST $20 \mathrm{FT}$.

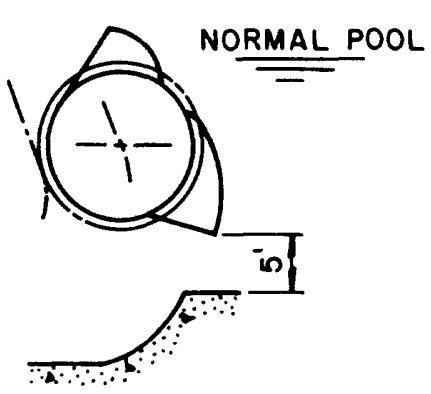

GATE OPEN 5 FT.

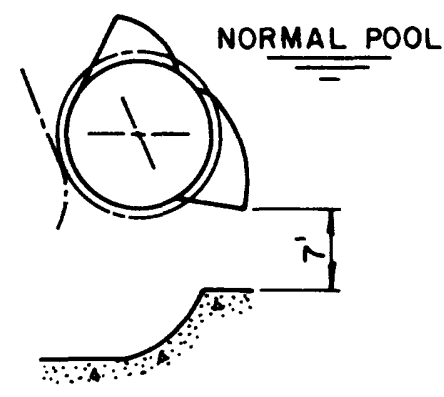

GATE OPEN 7 FT.

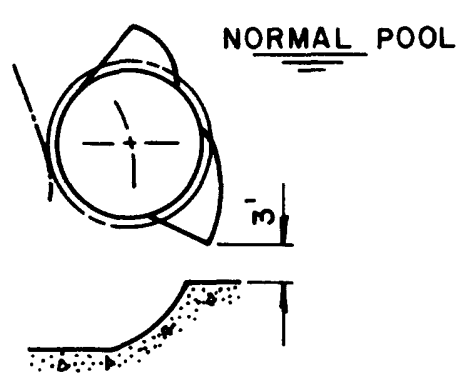

GATE OPEN 3 FT.

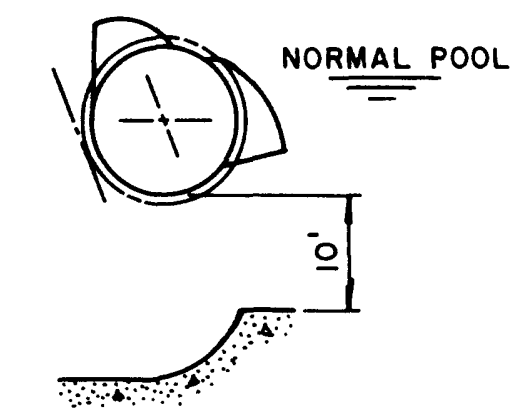

GATE OPEN IOFT.
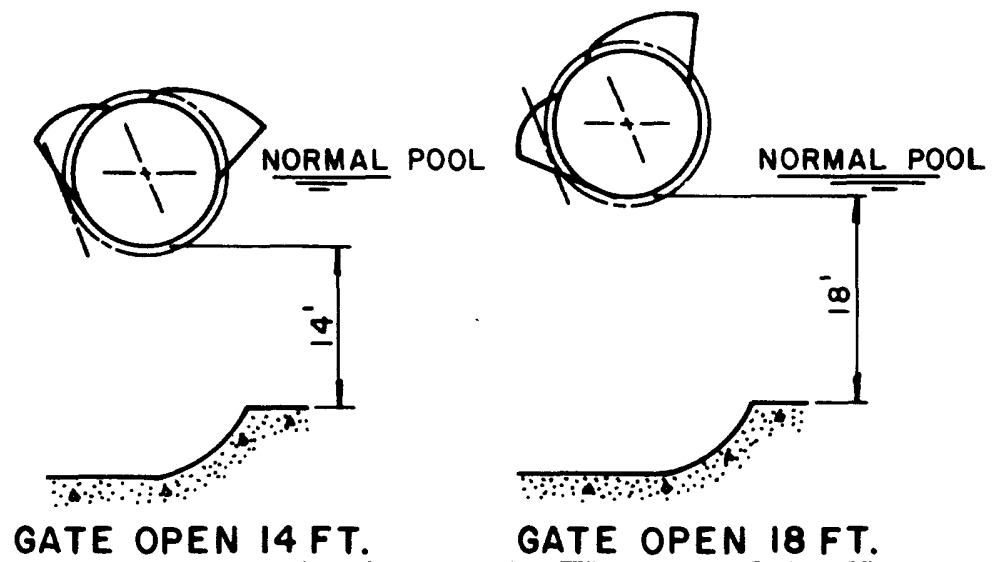

GATE OPEN 18 FT.

Figure 11.--Positions of roller gates for selected crests and openings (modified from U.S. Army Corps of Engineers, 1940, fig. 35). 
The exact gate opening where the control changes has not been defined. The resulting equation, relating the submerged-orifice coefficient, $\mathrm{C}_{\mathrm{gs}}$, to the orifice-submergence ratio, $h_{3} / h_{g}$, for the roller gates when the gates are open 7 feet or less is defined by the equation:

$$
\mathrm{C}_{g s}=0.75\left(\mathrm{~h}_{3} / \mathrm{h}_{\mathrm{g}}\right)^{-1.00}
$$

As noted by Collins (1977) and described by King and Brater (1954), many structures calibrated by the procedures outlined above are found to be independent or nearly independent of submergence. If the coefficient is independent of the submergence, the slope of the straight line relation will be -1.00 as in equation 13. When substituted for the coefficient in the submerged-orifice flow equation (2), the equation reduces to the free-oriiice equation (1). The coefficient computed for the roller gates at Dam 17 using the free-orifice equation (1) was 0.75 . The coefficient computed for the roller gates at Locks and Dams $11,12,13$ and 14 was 0.67 . The 0.67 coefficient is in total agreement with those in King and Brater (1954, table 26) for rectangular orifices with partially suppressed contraction.

For conditions when the gates are open greater than 7 feet and the orifice submergence ratio is less than 2.4 , the submerged-orifice coefficient, Cgs, for the Dam 17 roller gates can be described by the equation:

$$
C_{g s}=8.70\left(h_{3} / h_{g}\right)^{-3.80}
$$

The computed coefficients and the results of the measurements made for the roller gates at Dam 17 are listed in table 2 . 


\section{Submerged-Orifice Discharge Equation}

An equation for computing discharge for submerged-orifice flow when the roller gates are open 7 feet or less was developed using the submerged-orifice flow equation (2) and substituting equation 13 for the submerged-orifice coefficient, $\mathrm{C}_{g s}$. The resulting equation relating the discharge (Q) to the gate opening $\left(h_{g}\right)$ and the static-headloss $\left(h_{1}-h_{3}\right)$ is:

$$
Q=601 h_{g}\left(h_{1}-h_{3}\right)^{0.5}
$$

where $h_{1}-h_{3}=$ the difference between the pool and tailwater stages.

An equation for computing discharge for submerged-orifice flow when the roller gates are open greater than 7.0 feet and $h_{3} / h_{g}$ is less than 2.4 was developed using the submerged-orifice flow equation (2) and substituting equation 14 for the discharge coefficient, $\mathrm{C}_{g s}$. The resulting equation, relating the discharge (Q) to the static-tailwater head $\left(h_{3}\right)$, orificesubmergence ratio $\left(h_{3} / h_{g}\right)$ and the static-headloss $\left(h_{1}-h_{3}\right)$ is:

$$
Q=6,980 h_{3}\left(h_{3} / h_{g}\right)^{-3.80}\left(h_{1}-h_{3}\right)^{0.5}
$$

where $h_{3}=$ tailwater stage plus 10.70 feet, $h_{g}=$ gate opening and $h_{1}-h_{3}=$ difference between the pool and tailwater stages. 


\section{Free-Weir Flow Coefficient}

Discharge coefficients for free-weir flow for the roller gates in a submerged position were computed by solving equation 5 in table 1 for $\mathrm{C}_{\mathrm{sw}}$ using the results of the discharge measurements (table 2) that were made with the gates in a submerged position. A graph showing the relationship of $\mathrm{C}_{\mathrm{sw}}$ to the static-headwater head $\left(h_{1 s}\right)$ over the gate crest is shown in figure 12 . The equation relating the discharge coefficient to the headwater $\left(h_{1 s}\right)$ is:

$$
c_{\text {sw }}=8.67\left(h_{1 s}\right)^{-0.46}
$$

where $h_{1 s}=$ Gage reading $+0.04+($ pool stage -9.30$)$ for Dam 17 . The coefficient-headwater relation is further corroborated by data from Locks and Dams $11,12,13$ and 14 which are also shown in figure 12 . The +0.04 correction to the gage-indicator readings was derived from the observed pool stage at the point of zero flow over the gate crest. 


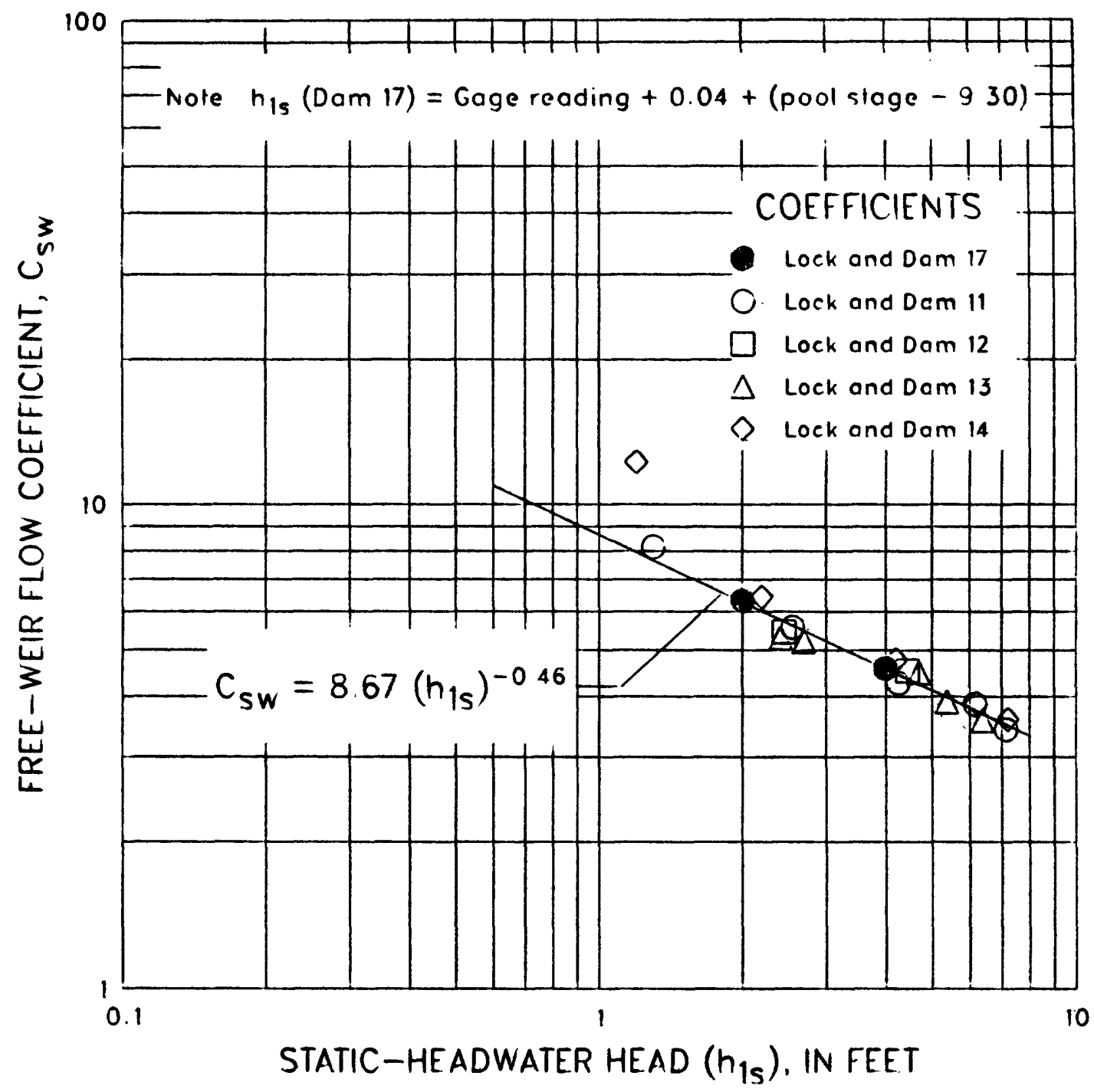

Figure 12.--Relation between free-weir flow coefficient and staticheadwater head for roller gates in submerged position for Lock and Dam 17.

\section{Free-Weir Discharge Equation}

An equation for computing discharge for free-weir flow for the roller gates in a submerged position at Dam 17 was developed using the free-weir flow equation (5) and substituting equation 17 for the free-weir coefficient, $\mathrm{C}_{\mathrm{Sw}}$. 
The resulting equation, graphically illustrated in figure 13, relating the discharge (Q) to the static-headwater head $\left(h_{1 s}\right)$ over the gate crest is:

$$
Q=867\left(h_{1 s}\right) 1.04
$$

where $h_{1 s}$ is as defined for equation 17 above. Also shown in figure 13 are the discharge measurements made at Locks and Dams 11, 12, 13 and 14. These measurements were used to corroborate the rating development for Lock and Dam 17.

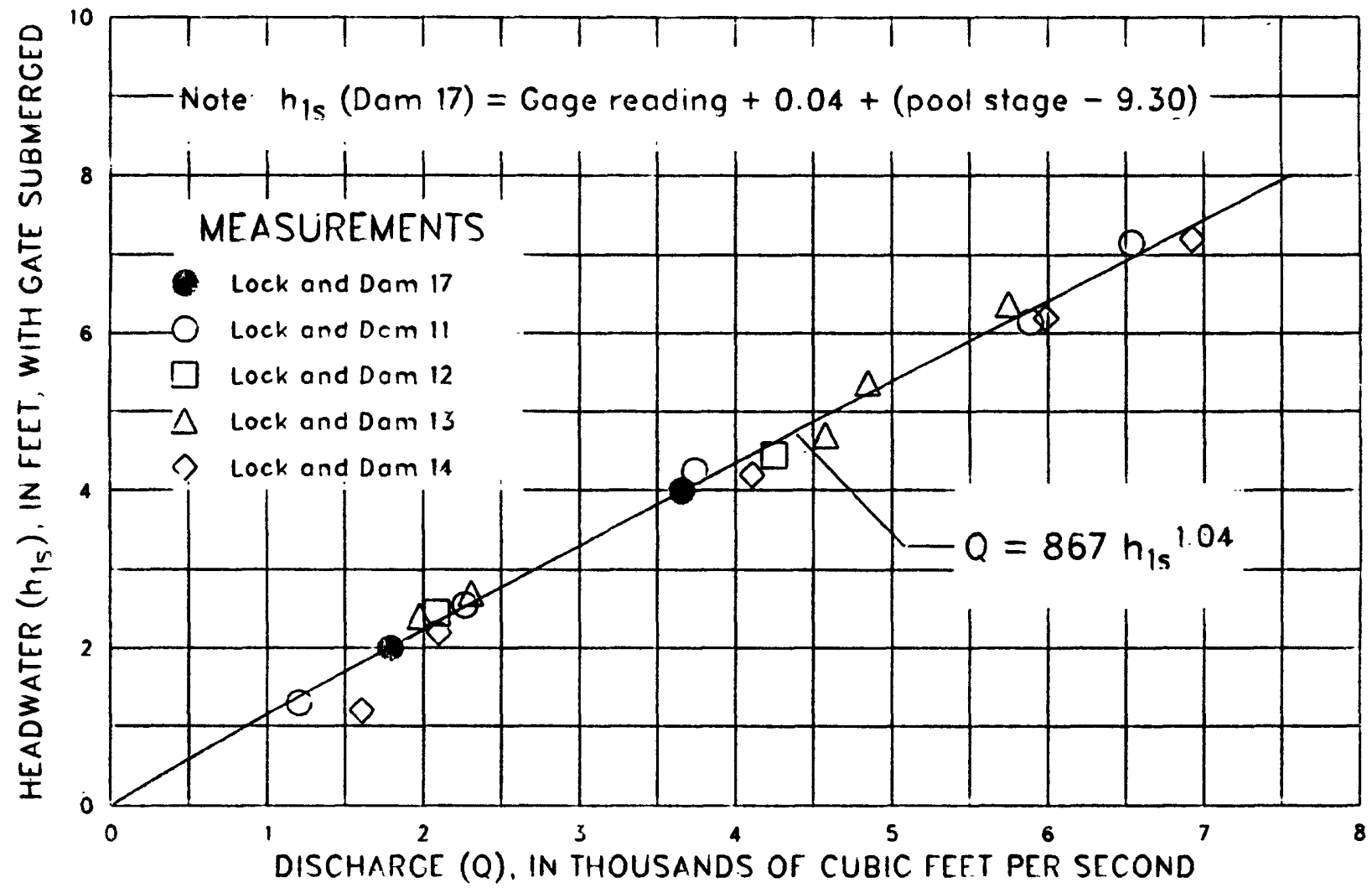

rigure 13.--Relation between discharge and headwater for free-weir flow for roller gates in submerged position for Lock and Dam 17 


\section{DISCHARGE EQUATIONS AND RATINGS}

The discharge equations applicable to the control gates when Dam 17 is in operation have been compiled and are listed in table 3 .

Rating tables for both the tainter and roller gates were developed for the predominant flow regime of submerged-orifice flow when Dam 17 is in operation. These ratings, tables 4 and 5, list discharges for tailwater stages and gate openings at 0.5 foot increments and are applicable only with the upstream pool stage at 9.30 feet $\left(h_{1}=20.00\right.$ feet $)$. Discharges for any other headwater, tailwater, and gate-opening relations encountered can easily be computed using the applicable equations in table 3 with a small programable computer.

Discharge rating curves for submerged-orifice flow at selected gate openings $\left(\mathrm{h}_{\mathrm{g}}\right)$ for the tainter and roller gates, prepared from laboratory tests using hydraulic models of gates, are shown in figures 14 and 15 . Corresponding discharge-rating curves defined by methods outlined in this report are shown for comparison. Discharges defined by the 2 methods for the tainter gates are comparable (within about 10 percent) until the gates are opened beyond the allowable gate opening for safe gate operation. At this point, the discharges defined by the two methods begin to diverge considerably. Discharges defined by the 2 methods for the roller gates are also comparable except those in the range of 7 to 8 feet of gate opening. In this range, the discharges computed by equation 16 increases at a much greater rate than those shown by the hydraulic-model rating curves. 


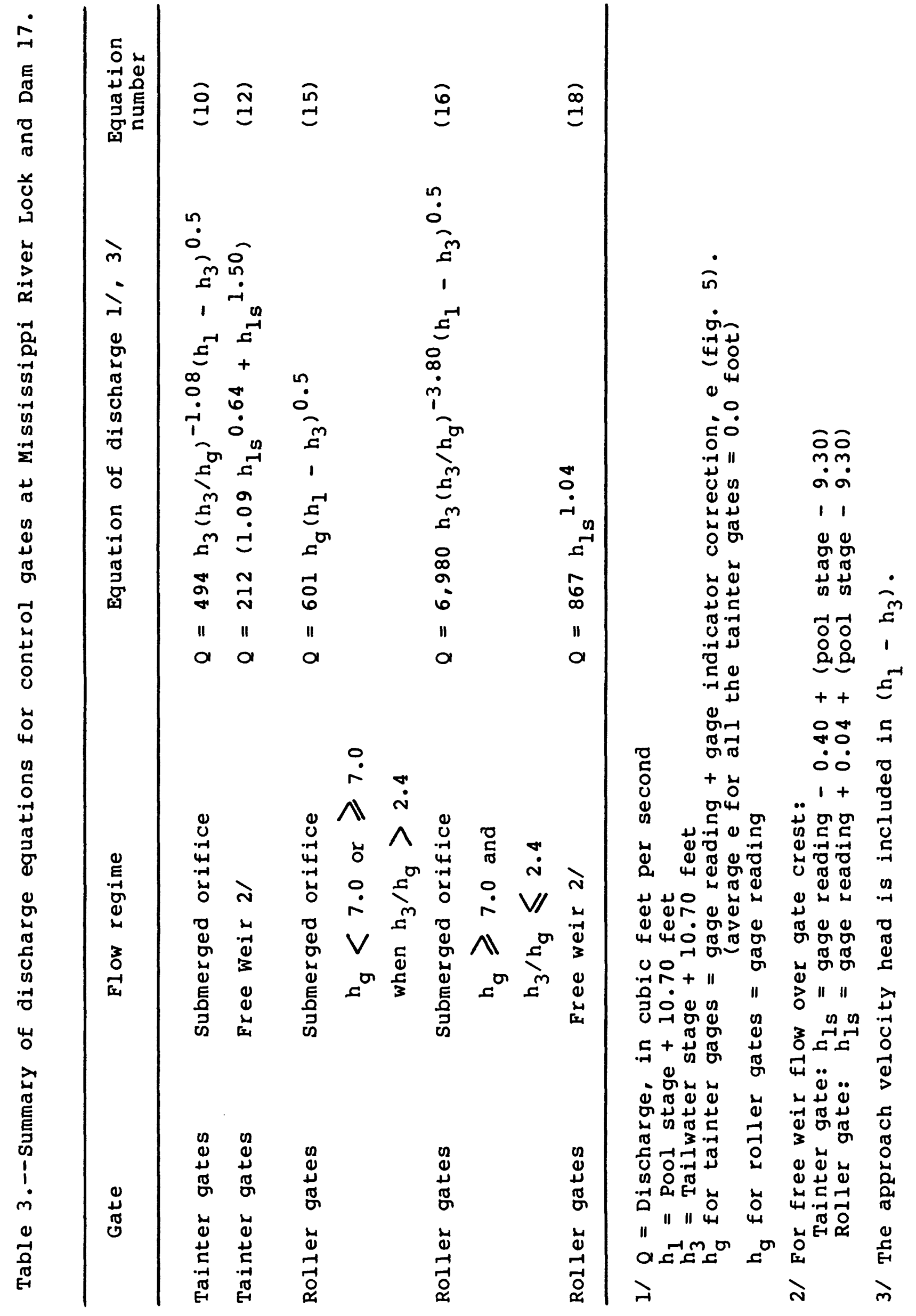




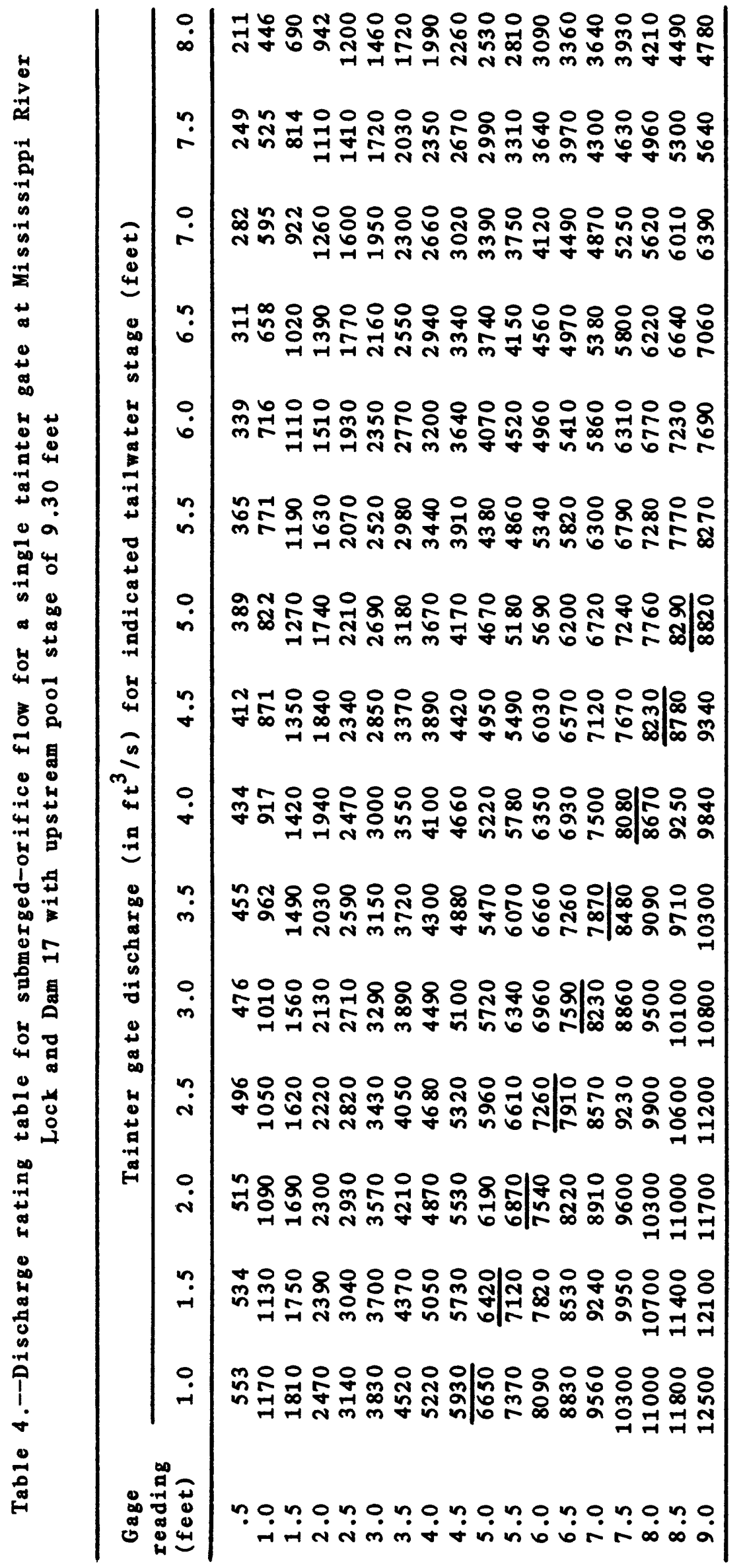

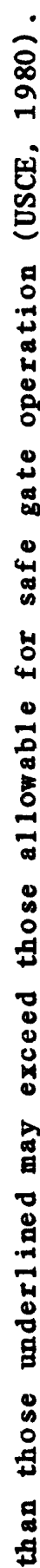




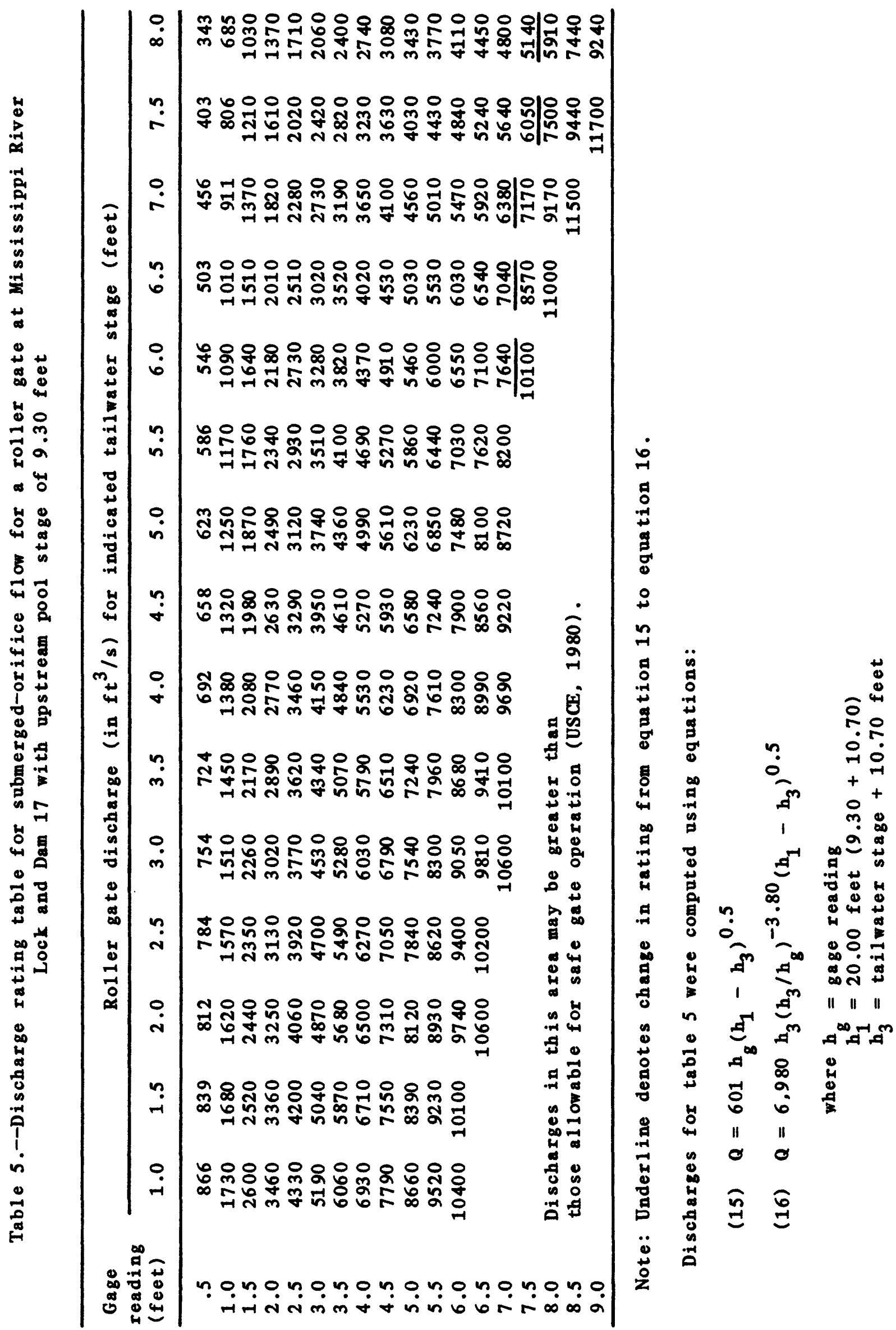




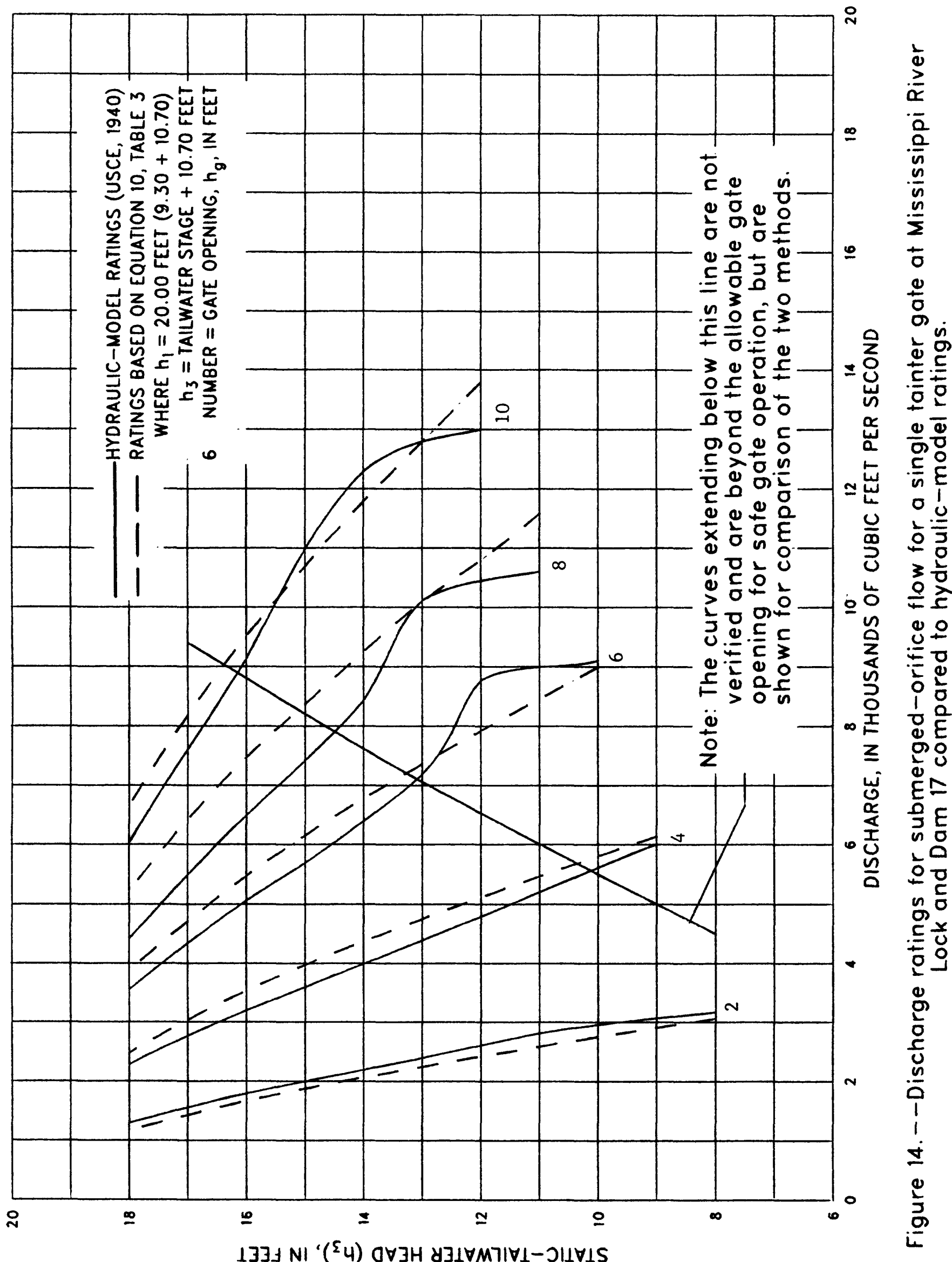




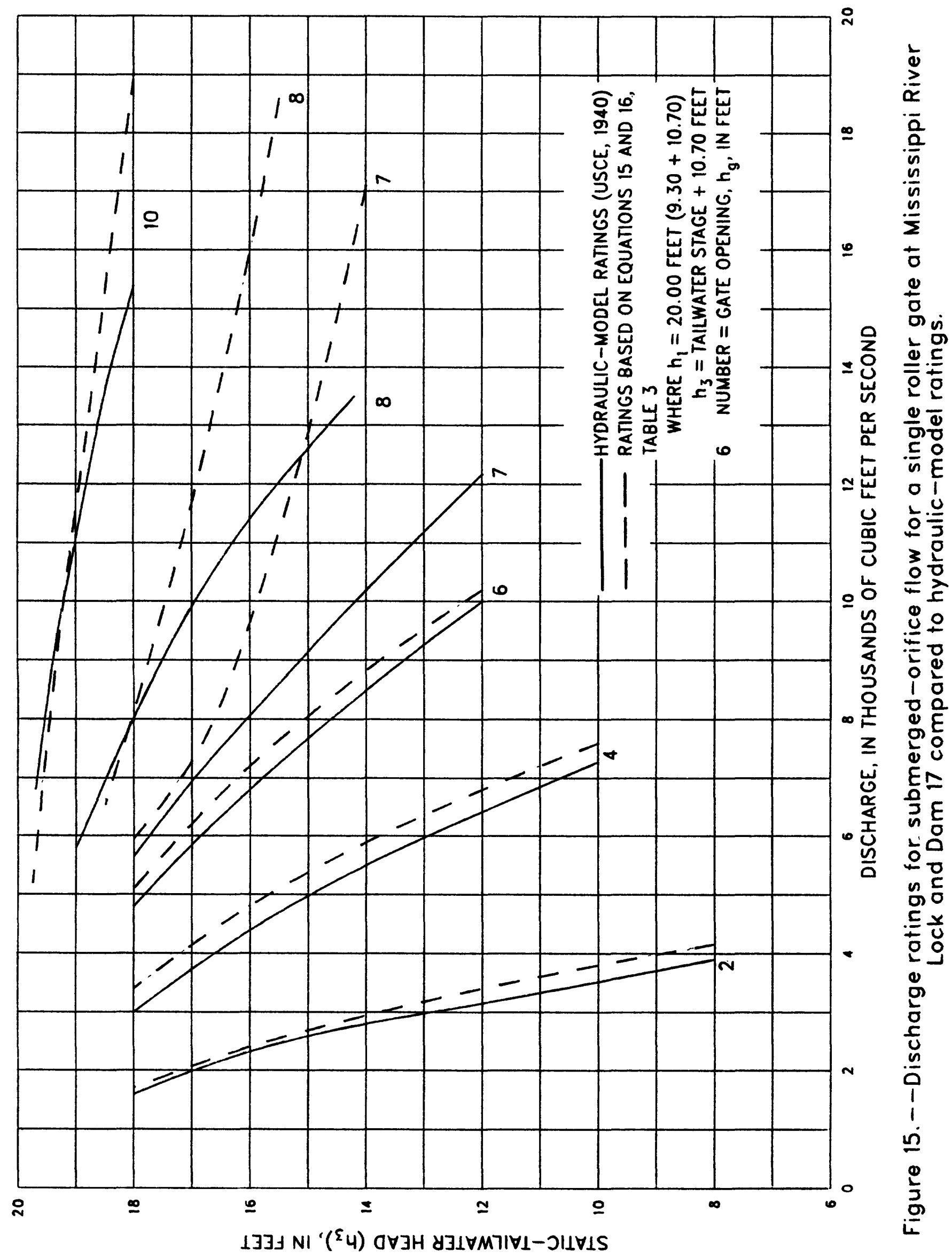


The equations in table 3 were used to compute the discharges for the gate settings indicated in the operation schedule, Plan A, shown in table 6 which is in use for operation of Dam 17. Discharges for the two methods were generally within 5 percent.

Table 6.--Comparison of rating discharges (column 1) to discharges specified in Gate Operation Schedule Plan A for Mississippi River Lock and Dam 17

[Hodified from U.S. Army Corps of Engineers, 1980, pl. 25]

\begin{tabular}{|c|c|c|c|c|c|c|c|c|c|c|c|c|c|c|}
\hline \multirow{3}{*}{$\begin{array}{l}\text { Rating } 1 / \\
\text { dis- } \\
\text { charge } \\
\text { (ft } \% / s)\end{array}$} & \multicolumn{3}{|c|}{ Gate Operation } & \multicolumn{11}{|c|}{$\begin{array}{l}\text { Schedule Plan A for controlled tailwater stages } \\
\text { with headwater stage of } 9.30 \text { feet }\end{array}$} \\
\hline & \multirow{2}{*}{$\begin{array}{l}\text { Dis- } \\
\text { charge } \\
\text { (ft } \% / 8)\end{array}$} & \multirow{2}{*}{$\begin{array}{c}\text { Tail- } \\
\text { water } \\
\text { stage } \\
\text { (feet) }\end{array}$} & \multirow{2}{*}{$\begin{array}{l}\text { Head } \\
\text { (feet) }\end{array}$} & \multicolumn{11}{|c|}{ Gate opening, (feet), for gate indicated } \\
\hline & & & & \multicolumn{4}{|c|}{ Tainter } & \multicolumn{3}{|c|}{ Roller } & \multicolumn{4}{|c|}{ Tainter } \\
\hline $\begin{array}{l}10,900 \\
12,800 \\
15,000\end{array}$ & $\begin{array}{l}11,000 \\
13,100 \\
15,300\end{array}$ & $\begin{array}{l}1.4 \\
1.6 \\
1.8\end{array}$ & $\begin{array}{l}7.9 \\
7.7 \\
7.5\end{array}$ & $\begin{array}{l}1.0 \\
1.0 \\
1.5\end{array}$ & $\begin{array}{l}1.0 \\
1.0 \\
1.5\end{array}$ & $\begin{array}{l}1.0 \\
1.0 \\
1.0\end{array}$ & $\begin{array}{l}1.0 \\
1.0 \\
1.0\end{array}$ & $\begin{array}{l}1.0 \\
1.0 \\
1.0\end{array}$ & $\begin{array}{l}1.0 \\
1.0 \\
1.0\end{array}$ & $\begin{array}{l}0.5 \\
1.0 \\
1.0\end{array}$ & $\begin{array}{l}0.5 \\
1.0 \\
1.0\end{array}$ & $\begin{array}{l}0.5 \\
1.0 \\
1.0\end{array}$ & $\begin{array}{l}0.5 \\
0.5 \\
1.0\end{array}$ & $\begin{array}{l}0.5 \\
0.5 \\
1.0\end{array}$ \\
\hline $\begin{array}{l}17,300 \\
19,300 \\
22,200 \\
24,000 \\
26,500\end{array}$ & $\begin{array}{l}17,500 \\
19,600 \\
21,800 \\
23,900 \\
25,900\end{array}$ & $\begin{array}{l}2.0 \\
2.2 \\
2.4 \\
2.6 \\
2.8\end{array}$ & $\begin{array}{l}7.3 \\
7.1 \\
6.9 \\
6.7 \\
6.5\end{array}$ & $\begin{array}{l}1.5 \\
1.5 \\
2.0 \\
2.0 \\
2.5\end{array}$ & $\begin{array}{l}1.5 \\
1.5 \\
2.0 \\
2.0 \\
2.5\end{array}$ & $\begin{array}{l}1.5 \\
1.5 \\
2.0 \\
2.0 \\
2.0\end{array}$ & $\begin{array}{l}1.5 \\
1.5 \\
2.0 \\
2.0 \\
2.0\end{array}$ & $\begin{array}{l}1.5 \\
1.5 \\
2.0 \\
2.0 \\
2.0\end{array}$ & $\begin{array}{l}1.5 \\
1.5 \\
1.5 \\
2.0 \\
2.0\end{array}$ & $\begin{array}{l}1.0 \\
1.5 \\
1.5 \\
2.0 \\
2.0\end{array}$ & $\begin{array}{l}1.0 \\
1.5 \\
1.5 \\
2.0 \\
2.0\end{array}$ & $\begin{array}{l}1.0 \\
1.5 \\
1.5 \\
1.5 \\
2.0\end{array}$ & $\begin{array}{l}1.0 \\
1.0 \\
1.0 \\
1.0 \\
1.5\end{array}$ & $\begin{array}{l}1.0 \\
1.0 \\
1.0 \\
1.0 \\
1.5\end{array}$ \\
\hline $\begin{array}{l}28,600 \\
30,100 \\
32,400 \\
34,500 \\
36,600\end{array}$ & $\begin{array}{l}27,900 \\
29,900 \\
31,800 \\
33,800 \\
35,500\end{array}$ & $\begin{array}{l}3.0 \\
3.2 \\
3.4 \\
3.6 \\
3.8\end{array}$ & $\begin{array}{l}6.3 \\
6.1 \\
5.9 \\
5.7 \\
5.5\end{array}$ & $\begin{array}{l}2.5 \\
2.5 \\
3.0 \\
3.0 \\
3.5\end{array}$ & $\begin{array}{l}2.5 \\
2.5 \\
3.0 \\
3.0 \\
3.0\end{array}$ & $\begin{array}{l}2.5 \\
2.5 \\
3.0 \\
3.0 \\
3.0\end{array}$ & $\begin{array}{l}2.5 \\
2.5 \\
2.5 \\
3.0 \\
3.0\end{array}$ & $\begin{array}{l}2.5 \\
2.5 \\
2.5 \\
3.0 \\
3.0\end{array}$ & $\begin{array}{l}2.0 \\
2.5 \\
2.5 \\
3.0 \\
3.0\end{array}$ & $\begin{array}{l}2.0 \\
2.5 \\
2.5 \\
3.0 \\
3.0\end{array}$ & $\begin{array}{l}2.0 \\
2.5 \\
2.5 \\
2.5 \\
3.0\end{array}$ & $\begin{array}{l}2.0 \\
2.0 \\
2.5 \\
2.5 \\
3.0\end{array}$ & $\begin{array}{l}2.0 \\
2.0 \\
2.0 \\
2.0 \\
2.5\end{array}$ & $\begin{array}{l}1.5 \\
1.5 \\
2.0 \\
2.0 \\
2.5\end{array}$ \\
\hline $\begin{array}{l}38,300 \\
40,500 \\
42,700 \\
44,400 \\
46,400\end{array}$ & $\begin{array}{l}37,200 \\
39,100 \\
41,000 \\
42,900 \\
44,600\end{array}$ & $\begin{array}{l}4.0 \\
4.2 \\
4.4 \\
4.6 \\
4.8\end{array}$ & $\begin{array}{l}5.3 \\
5.1 \\
4.9 \\
4.7 \\
4.5\end{array}$ & $\begin{array}{l}3.5 \\
3.5 \\
4.0 \\
4.0 \\
4.5\end{array}$ & $\begin{array}{l}3.5 \\
3.5 \\
4.0 \\
4.0 \\
4.5\end{array}$ & $\begin{array}{l}3.5 \\
3.5 \\
4.0 \\
4.0 \\
4.5\end{array}$ & $\begin{array}{l}3.5 \\
3.5 \\
4.0 \\
4.0 \\
4.5\end{array}$ & $\begin{array}{l}3.5 \\
3.5 \\
3.5 \\
4.0 \\
4.0\end{array}$ & $\begin{array}{l}3.0 \\
3.5 \\
3.5 \\
4.0 \\
4.0\end{array}$ & $\begin{array}{l}3.0 \\
3.5 \\
3.5 \\
4.0 \\
4.0\end{array}$ & $\begin{array}{l}3.0 \\
3.5 \\
3.5 \\
4.0 \\
4.0\end{array}$ & $\begin{array}{l}3.0 \\
3.5 \\
3.5 \\
3.5 \\
4.0\end{array}$ & $\begin{array}{l}2.5 \\
3.0 \\
3.5 \\
3.5 \\
3.5\end{array}$ & $\begin{array}{l}2.5 \\
2.5 \\
3.0 \\
3.0 \\
3.5\end{array}$ \\
\hline $\begin{array}{l}48,200 \\
50,600 \\
51,900 \\
53,600 \\
55,800\end{array}$ & $\begin{array}{l}46,300 \\
48,000 \\
49,700 \\
51,300 \\
53,000\end{array}$ & $\begin{array}{l}5.0 \\
5.2 \\
5.4 \\
5.6 \\
5.8\end{array}$ & $\begin{array}{l}4.3 \\
4.1 \\
3.9 \\
3.7 \\
3.5\end{array}$ & $\begin{array}{l}4.5 \\
5.0 \\
5.0 \\
5.5 \\
6.0\end{array}$ & $\begin{array}{l}4.5 \\
5.0 \\
5.0 \\
5.5 \\
6.0\end{array}$ & $\begin{array}{l}4.5 \\
5.0 \\
5.0 \\
5.5 \\
6.0\end{array}$ & $\begin{array}{l}4.5 \\
5.0 \\
5.0 \\
5.5 \\
6.0\end{array}$ & $\begin{array}{l}4.5 \\
5.0 \\
5.0 \\
5.5 \\
5.5\end{array}$ & $\begin{array}{l}4.5 \\
4.5 \\
5.0 \\
5.5 \\
5.5\end{array}$ & $\begin{array}{l}4.5 \\
4.5 \\
5.0 \\
5.0 \\
5.5\end{array}$ & $\begin{array}{l}4.5 \\
4.5 \\
5.0 \\
5.0 \\
5.5\end{array}$ & $\begin{array}{l}4.0 \\
4.5 \\
5.0 \\
5.0 \\
5.0\end{array}$ & $\begin{array}{l}4.0 \\
4.0 \\
4.5 \\
4.5 \\
5.0\end{array}$ & $\begin{array}{l}3.5 \\
4.0 \\
4.0 \\
4.0 \\
4.5\end{array}$ \\
\hline $\begin{array}{l}57,600 \\
59,100 \\
60,100 \\
60,600 \\
62,600\end{array}$ & $\begin{array}{l}54,700 \\
56,300 \\
58,000 \\
59,900 \\
61,800\end{array}$ & $\begin{array}{l}6.0 \\
6.2 \\
6.4 \\
6.6 \\
6.8\end{array}$ & $\begin{array}{l}3.3 \\
3.1 \\
2.9 \\
2.7 \\
2.5\end{array}$ & $\begin{array}{l}6.5 \\
6.5 \\
7.0 \\
7.0 \\
7.0\end{array}$ & $\begin{array}{l}6.5 \\
6.5 \\
7.0 \\
7.0 \\
7.0\end{array}$ & $\begin{array}{l}6.0 \\
6.5 \\
7.0 \\
7.0 \\
7.0\end{array}$ & $\begin{array}{l}6.0 \\
6.5 \\
7.0 \\
7.0 \\
8.0\end{array}$ & $\begin{array}{l}6.0 \\
6.5 \\
7.0 \\
7.0 \\
8.0\end{array}$ & $\begin{array}{l}6.0 \\
6.5 \\
6.5 \\
7.0 \\
7.0\end{array}$ & $\begin{array}{l}6.0 \\
6.5 \\
6.5 \\
7.0 \\
7.0\end{array}$ & $\begin{array}{l}5.5 \\
6.0 \\
6.0 \\
6.5 \\
6.5\end{array}$ & $\begin{array}{l}5.5 \\
5.5 \\
6.0 \\
6.5 \\
6.5\end{array}$ & $\begin{array}{l}5.0 \\
5.5 \\
5.5 \\
6.0 \\
6.5\end{array}$ & $\begin{array}{l}5.0 \\
5.0 \\
5.5 \\
6.0 \\
6.0\end{array}$ \\
\hline $\begin{array}{l}65,700 \\
64,500\end{array}$ & $\begin{array}{l}63,700 \\
65,500\end{array}$ & $\begin{array}{l}7.0 \\
7.2\end{array}$ & $\begin{array}{l}2.3 \\
2.1\end{array}$ & $\begin{array}{l}7.0 \\
7.0\end{array}$ & $\begin{array}{l}7.0 \\
7.0\end{array}$ & $\begin{array}{l}7.0 \\
8.0\end{array}$ & $\begin{array}{l}7.0 \\
8.0\end{array}$ & $\begin{array}{l}8.0 \\
8.0\end{array}$ & $\begin{array}{l}8.0 \\
8.0\end{array}$ & $\begin{array}{l}8.0 \\
8.0\end{array}$ & $\begin{array}{l}7.0 \\
8.0\end{array}$ & $\begin{array}{l}7.0 \\
7.0\end{array}$ & $\begin{array}{l}6.5 \\
7.0\end{array}$ & $\begin{array}{l}6.5 \\
6.5\end{array}$ \\
\hline
\end{tabular}

$1 /$ Computed using equations in table 3 with headwater stage of 9.30 feet. 


\section{SUMMARY}

Current-meter discharge measurements made in the forebays of the tainter and roller gates of Lock and Dam 17 were used to develop discharge coefficients and equations of discharge for submerged-orifice and free-weir flow for all the gates.

Methodology has been described to compute the actual gate openings of the tainter gates. The gate-position indicator gages for the tainter gates could be accurately set to the true gate opening $\left(h_{g}\right)$ using the techniques described in case the gages were accidentally knocked out of alignment or if the bottom seals on the gates were changed. The deviation of the discharge from the rating discharge for the individual gates could be minimized by adjusting the gate-position indicators to more nearly reflect the computed gate opening, $h_{g}$.

Discharge rating tables were developed for discrete combinations of tailwater stages and gate openings for submerged-orifice flow, which is the predominant flow regime when the dam is in operation.

Comparisons of the discharges defined by the hydraulic-model ratings and those computed by the equations developed in this study are given for selected gate openings. Discharges defined by methods outlined in this study are also given for comparison to those used in the operation schedule, Plan A, which is in use for the operation of Lock and Dam 17. 


\section{SELECTED REFERENCES}

American Society of Civil Engineers, 1962, Nomenclature for hydraulics: ASCE Manuals and Reports No. 43, 501 p.

Collins, D.L., 1977, Computation of records of streamflow at control structure: U.S. Geological Survey Water-Resources Investigations $77-8,57 \mathrm{p}$.

Creager, W.P., and Justin, J.D., 1950, Hydro-electric Handbook: New York, John Wiley, 1151 p.

Davis, C.V., and Sorensen, K.E., 1952, Handbook of Applied Hydraulics: McGraw-Hill, 800 p.

Heinitz, A.J., 1985, Discharge Ratings For Control Gates at Mississippi River Lock and Dam 11, Dubuque, Iowa: U.S. Geological Survey Water-Resources Investigations Report $85-4105,43 \mathrm{p}$.

, 1985, Discharge Ratings for Control Gates at Mississippi River Lock and Dam 14, Le Claire, Iowa: U.S. Geological Survey Water-Resources Investigations Report $85-4261,38 \mathrm{p}$.

1 1986, Discharge Ratings for Control Gates at Mississippi River Lock and Dam 12, Bellevue, Iowa: U.S. Geological Survey Water-Resources Investigations Report $86-4135,43 \mathrm{p}$.

1 1986, Discharge Ratings for Control Gates at Mississippi River Lock and Dam 13, Fulton, Illinois: U.S. Geological Survey Water-Resources Investigations Report $86-4134,43 \mathrm{p}$.

- 1986, Discharge Ratings for Control Gates at Mississippi River Lock and Dam 16, Muscatine, Iowa: U.S. Geological Survey Water-Resources Investigations Report $86-4136,36$ p.

1986, Discharge Ratings for Control Gates at Mississippi River Lock and Dam 22, Saverton, Missouri: U.S. Geological Survey Water-Resources Investigations Report $86-4137,37 \mathrm{p}$. 
REFERENCES.... continued

1987, Discharge Ratings for Control Gates at MissisSippi River Lock and Dam 18, Gladstone, Illinois: U.S. Geological Survey Water-Resources Investigations Report $87-4110,44 \mathrm{p}$.

1987, Discharge Ratings for Control Gates at Mississippi River Lock and Dam 20, Canton, Missouri: U.S. Geological Survey Water-Resources Investigations Report $87-4149,44 \mathrm{p}$.

King, H.W., and Brater, E.F., 1954, Handbook of hydraulics (4th ed.): New York, McGraw-Hill, 640 p.

Rantz, S.E. and others, 1982, Measurement and computation of streamflow, Volume 1. Measurement of stage and discharge: U.S. Geological Survey Water-Supply Paper 2175, 284 p.

Rouse, Hunter, 1949, Engineering hydraulics, Iowa Institute of Hydraulic Research, State University of Iowa: New York, John Wiley, 1039 p.

U.S. Army Corps of Engineers, 1939, Laboratory tests on hydraulic models of roller gate stilling basins: Rock Island, Illinois, 279 p.

1940 a, Laboratory tests on hydraulic model to determine roller gate coefficients for upper Mississippi River navigation dams: Rock Island, Illinois, 72 p.

$1940 \mathrm{~b}$, Laboratory tests on hydraulic model of Lock and Dam No. 1l, Mississippi River, Dubuque, Iowa: Rock Island, Illinois, $111 \mathrm{p}$.

1978, Mississippi River Lock and Dam 17, Dam pier position data: Rock Island, Illinois, 1 p.

1980, Upper Mississippi River basin, Mississippi Rivernine foot channel, Appendix 17, Master reservoir regulation manual, Lock and Dam No. 17: Rock Island, Illinois, 93 p. 